Article

\title{
Spatiotemporal Evolution of Wetland Eco-Hydrological Connectivity in the Poyang Lake Area Based on Long Time-Series Remote Sensing Images
}

\author{
Yang Xia ${ }^{1,2}$, Chaoyang Fang ${ }^{1,2, *}$, Hui Lin ${ }^{1,2}$, Huizhong Li $^{1,2}$ and Bobo Wu ${ }^{1,2}$ \\ 1 School of Geography and Environment, Jiangxi Normal University, Nanchang 330022, China; \\ xiayang@jxnu.edu.cn (Y.X.); huilin@cuhk.edu.hk (H.L.); lihuizhong@jxnu.edu.cn (H.L.); \\ 201950000004@jxnu.edu.cn (B.W.) \\ 2 Key Laboratory of Poyang Lake Wetland and Watershed Research, Ministry of Education, \\ Nanchang 330022, China \\ * Correspondence: fcy@jxnu.edu.cn
}

check for updates

Citation: Xia, Y.; Fang, C.; Lin, H.; Li, H.; Wu, B. Spatiotemporal Evolution of Wetland Eco-Hydrological Connectivity in the Poyang Lake Area Based on Long Time-Series Remote Sensing Images. Remote Sens. 2021, 13 , 4812. https://doi.org/10.3390/ rs13234812

Academic Editors: Bingfang Wu, Yuan Zeng and Dan Zhao

Received: 26 October 2021

Accepted: 25 November 2021

Published: 27 November 2021

Publisher's Note: MDPI stays neutral with regard to jurisdictional claims in published maps and institutional affiliations.

Copyright: (c) 2021 by the authors Licensee MDPI, Basel, Switzerland. This article is an open access article distributed under the terms and conditions of the Creative Commons Attribution (CC BY) license (https:// creativecommons.org/licenses/by/ $4.0 /)$.

\begin{abstract}
Hydrological connectivity is important for maintaining the stability and function of wetland ecosystems. Small-scale hydrological connectivity restricts large-scale hydrological cycle processes. However, long-term evolutionary studies and quantitative evaluation of the hydrological connectivity of wetlands in the Poyang Lake area have not been sufficiently conducted. In this study, we collected 21 Landsat remote sensing images and extracted land use data from 1989 to 2020, introducing a morphological spatial pattern analysis model to assess the wetland hydrological connectivity. A comprehensive method for evaluating the hydrological connectivity of wetlands was established and applied to the Poyang Lake area. The results showed that, over the course of 31 years, the wetland landscape in the Poyang Lake area changed dramatically, and the wetland area has generally shown a decreasing and then increasing trend, among which the core wetland plays a dominant role in the hydrological connectivity of the Poyang Lake area. In addition, the hydrological connectivity decreases as the core wetland area decreases. From 1989 to 2005, the landscape in the Poyang Lake area focused mainly on the transition from wetland to non-wetland. From 2005 to 2020, the conversion of wetland landscape types shows a clear reversal compared to the previous period, showing a predominant shift from non-wetland to wetland landscapes. The eco-hydrological connectivity of the wetlands in the Poyang Lake area from 1989 to 2020 first decreased, and then increased after 2005. In the early stage of the study (1989-2005), we found that the connectivity of 0.3444 in 2005 was the lowest value in the study period. A resolution of $30 \mathrm{~m}$ and an edge effect width of $60 \mathrm{~m}$ were optimal for studying the hydrological connectivity of wetlands in the Poyang Lake area. The main drivers of the changes in hydrological connectivity were precipitation and the construction of large-scale water conservation projects, as well as changes in land use. This study provides a good basis for assessing hydrological connectivity in a meaningful way, and is expected to provide new insights for maintaining and restoring biodiversity and related ecosystem services in the Poyang Lake area.
\end{abstract}

Keywords: wetland; morphological spatial pattern analysis (MSPA); hydrological connectivity composite index; spatial and temporal evolution; Poyang Lake area

\section{Introduction}

Wetlands, along with forests and oceans, are among the three dominant ecosystems in the world. They are an important part of the natural ecological space, and play an important role in water conservation, water purification, flood and drought control, climate regulation, and biodiversity maintenance. They also support the sustainable development of human economies, societies, and living environments [1,2]. Hydrological connectivity refers to the process of transferring various materials, energies, and organisms within or between elements of a hydrological cycle, using water as a medium [3,4], including spatial 
three-dimensional changes as well as temporal dynamic changes [5]. Wetland hydrological processes play a direct and important role in the processes of formation, development, succession, and extinction of wetlands [6-8]. In wetland ecosystems, the transfer of materials, energy, and information is mostly related to wetland hydrological processes, and is accompanied by the water cycle, which makes hydrological connectivity very important for the stability and maintenance of wetlands [9]. The blockage of wetland connectivity due to urban development and agricultural exploitation has attracted widespread international attention, and the Ramsar Secretariat made trans-basin hydrological assessments a research priority in 2015 [10]. Therefore, clarifying spatial patterns and comprehensive indicator models of wetland hydrological connectivity, and considering wetland restoration from a perspective of hydrological connectivity, are major scientific issues to be addressed in wetland science.

Wetlands in the Poyang Lake area in the middle and lower reaches of the Yangtze River are typical global river-lake silted freshwater wetlands, and their hydrological connectivity is related to the ecological safety of the Poyang Lake basin, and even the Yangtze River basin. This is important to consider in order to improve the regional ecological environment, and to realize a harmonious coexistence between people and nature. Multisource long time series of remote sensing data are widely used to monitor changes in wetlands [11-13], including changes in wetland landscape patterns [14], ecosystem health [15], and connectivity [16]. Li et al. [17] attempted to combine hydrodynamic modeling and statistical methods to study hydrological connectivity and its relationship to water quality in nine seasonal lakes within the floodplain of Poyang Lake. Using geostatistical methods in combination with remote sensing, Liu et al. [18] found that the main lake stage plays a dominant role in determining the hydrological connectivity during flooding and ebb in the Poyang Lake region. There is a good theoretical understanding of hydrological connectivity, but most current studies use one approach — whether by prioritizing the conservation and restoration of multiple wetlands, or by assessing the hydrological connectivity of individual wetlands, this is based on a quantitative assessment [19-22]. Methods for evaluating the hydrological connectivity of wetlands mainly include percolation theory [23], in situ monitoring [24], graph theory [25], remote sensing [26,27], isotope tracing [28], connectivity index [29,30], and hydrological modeling [31,32]. The above methods, such as connectivity indices, have been widely used in research, and have provided good results, but they are also highly generalized, and can give only a single value, without information on spatial distribution [30]. Research on the evolution of the spatial distribution of wetlands has yet to be strengthened.

In recent years, morphological spatial pattern analysis (MSPA) has been used successfully to analyze various landscape morphological changes [33-35]. MSPA applies a series of image processing techniques to raster layers, thus dividing target features into different landscape categories — such as the core and islet areass-in order to study the morphological mechanisms of different features across non-crossing morphological types [36]. However, MSPA mainly focuses on the construction and optimization of forests, green infrastructure, and ecological network patterns [37-39], while a limited amount of research has been conducted on wetlands. MSPA has also been limited to the study of the effects of parameter changes on landscape patterns [40,41]. In terms of quantitative evaluations of hydrological connectivity, most methods are derived from water system connectivity assessments, and there is no comprehensive method for assessing the hydrological connectivity of wetland systems. Ghaderpour et al. [42] applied the least-squares wavelet software (LSWAVE) to assess trends and seasonal components of the six-decade-long climate and discharge time series for the Athabasca River basin (ARB) in Alberta, Canada, and to study the effects of climate change on streamflow. Soil and water assessment tool (SWAT) models combined with the application of geographic information systems (GISs) provide good alternatives for water resources and environmental assessments [43]. However, the above methods use a single-indicator comparison method to assess one or more aspects of water quality evolution, biology, and soil hydrological connectivity [44-47]. In this study, we established a comprehensive method for evaluating the hydrological connectivity of 
wetlands from multiple perspectives, taking into account the degree of landscape and functional connectivity as well as the driving elements of the system. Our findings are extremely important, with theoretical and practical significance for the restoration of wetland eco-hydrological connectivity.

We studied the hydrological connectivity in the Poyang Lake area over a long time series, overcoming the shortcomings of traditional hydrological connectivity limited to a single value, and analyzed the hydrological connectivity over the past 31 years. Meanwhile, we propose a systematic and comprehensive evaluation method to assess the degree of hydrological connectivity of wetlands in the Poyang Lake area on different spatial and temporal scales, and to take into account the degree of dynamic feedback of hydrological connectivity to different driving factors. The effects of different scale settings on MSPA results and driving factors that cause the evolution of the hydrological connectivity of wetlands in the Poyang Lake area were investigated in terms of particle size and edge width selection. The methods of this study can be extended to the evaluation of hydrological connectivity in other areas, and can provide theoretical references for the conservation and restoration of wetlands in the Poyang Lake area.

\section{Materials and Methods}

\subsection{Study Area and Data}

\subsubsection{Study Area}

The Poyang Lake area lies on the south bank of the junction of the middle and lower reaches of the Yangtze River, in the north of Jiangxi Province; it is bounded between $28^{\circ} 24^{\prime} \mathrm{N}-29^{\circ} 46^{\prime} \mathrm{N}$ and $115^{\circ} 49^{\prime} \mathrm{E}-116^{\circ} 46^{\prime} \mathrm{E}$, and its administrative area includes 13 counties and cities, including Nanchang City, Jiujiang City and Poyang County, with a total land area of $203,378 \mathrm{~km}^{2}$ (Figure 1). The terrain in the region is gentle-mostly hilly and mountainous. The Poyang Lake area extends from the center to the surroundings, which are mostly lakeside plains and low hill remnants, thus forming basin-like terrain with high edges and a lower middle part. The Poyang Lake area has a subtropical humid monsoon climate, with cold winters and springs, rainy summers, and dry autumns. The average annual temperature in the area is between 16.6 and $17.5^{\circ} \mathrm{C}$, the average annual sunshine hours are 1750-2105 h, and the average annual precipitation is between 1368 and $1796 \mathrm{~mm}$ [48].

Poyang Lake was one of the first wetlands in China to join the Ramsar Convention on Wetlands, and is an important reserve of ecological function in China; it is also a globally important ecological zone, as designated by the World Wildlife Foundation (WWF) $[49,50]$. As the largest freshwater lake in China, the water level of Poyang Lake varies dramatically, often forming a landscape of "A piece of abundant water and a line of dry water" [51]. In recent decades, the wetland ecosystem has been continuously degraded due to climate change and human activities. Strong positive feedbacks between wetland degradation, reduced hydrological connectivity, and water scarcity, as well as spatial and temporal inequalities, have attracted increasing attention $[52,53]$.

\subsubsection{Data}

To ensure the most similar ground state, a total of 21 Landsat TM/OLI remote sensing images (Table 1) were selected as the data sources for this study over the seven periods from 1989, 1995, 2000, 2005, 2010, 2015, and May-September 2020 (abundant water period). The remote sensing image data were downloaded from the USGS website [54]. The spatial resolution is $30 \mathrm{~m}$, the cloudiness of all of the selected images is less than $5 \%$, the imaging quality is good, and the overall impact on the image interpretation effect is small. We also used $30 \mathrm{~m}$ DEM elevation data taken from the geospatial data cloud [55] and the GF-1 satellite data to help in the classification interpretation. For the construction of the hydrological connectivity index, we used precipitation data downloaded from the China Meteorological Data Network [56], and population data were taken from the Jiangxi Provincial Statistical Yearbook. 


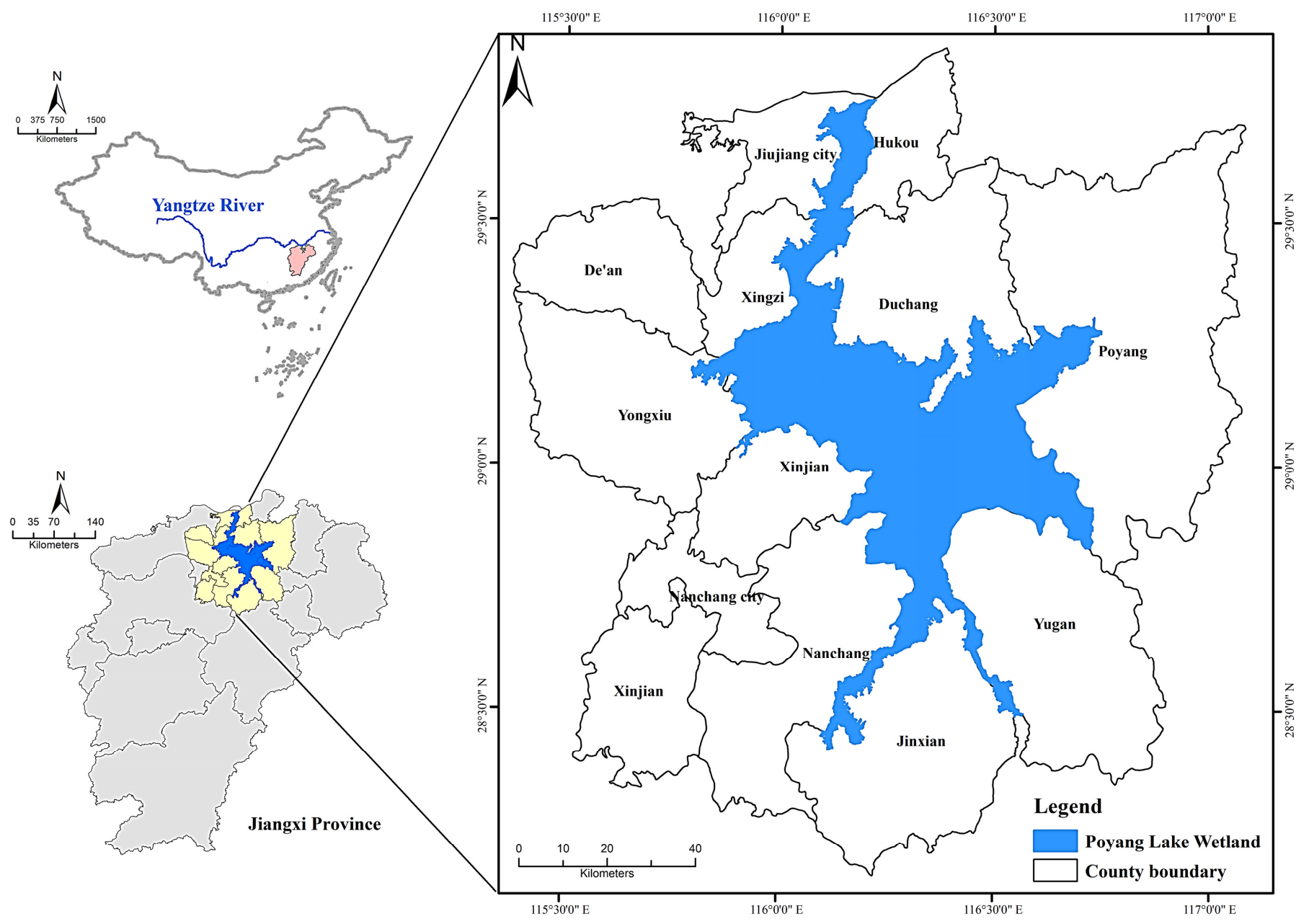

Figure 1. Location of the Poyang Lake area.

Table 1. Remote sensing images selected for this study.

\begin{tabular}{cccc}
\hline \multirow{2}{*}{ Image Acquired Date } & \multicolumn{3}{c}{ Track Number } \\
\cline { 2 - 4 } & $\mathbf{1 2 1 / 0 3 9}$ & $\mathbf{1 2 1 / 0 4 0}$ & $\mathbf{1 2 2 / 0 4 0}$ \\
\hline $1989(\mathrm{TM})$ & 15071989 & 15071989 & 24091989 \\
$1995(\mathrm{TM})$ & 02091995 & 02091995 & 25091995 \\
$2000(\mathrm{TM})$ & 10092000 & 15092000 & 18062000 \\
$2005(\mathrm{TM})$ & 13092005 & 29092005 & 20092005 \\
$2010(\mathrm{TM})$ & 19092010 & 18082010 & 19092010 \\
$2015(\mathrm{OLI})$ & 09092015 & 09092015 & 02102015 \\
$2020(\mathrm{OLI})$ & 06092020 & 06092020 & 28082020 \\
\hline
\end{tabular}

\subsection{Methodology}

Figure 2 illustrates the technical framework for this study. Landsat images were first pre-processed, then decoded and classified using an object-oriented classification method, and accuracy verification was performed. The decoded images were reclassified into binary images with wetlands and other land classes and imported into the Guidos Toolbox software for MSPA analysis, in order to obtain landscape classification files and data on the spatial morphological evolution of the hydrological connectivity. At the same time, a hydrological connectivity index was created, and the collected and processed index data were normalized. Index weights were determined using Yaahp software, and the fuzzy integrated hierarchy method was used. The hydrological connectivity of Poyang Lake was then calculated from year to year. Finally, the results of spatial and temporal evolution were obtained. 


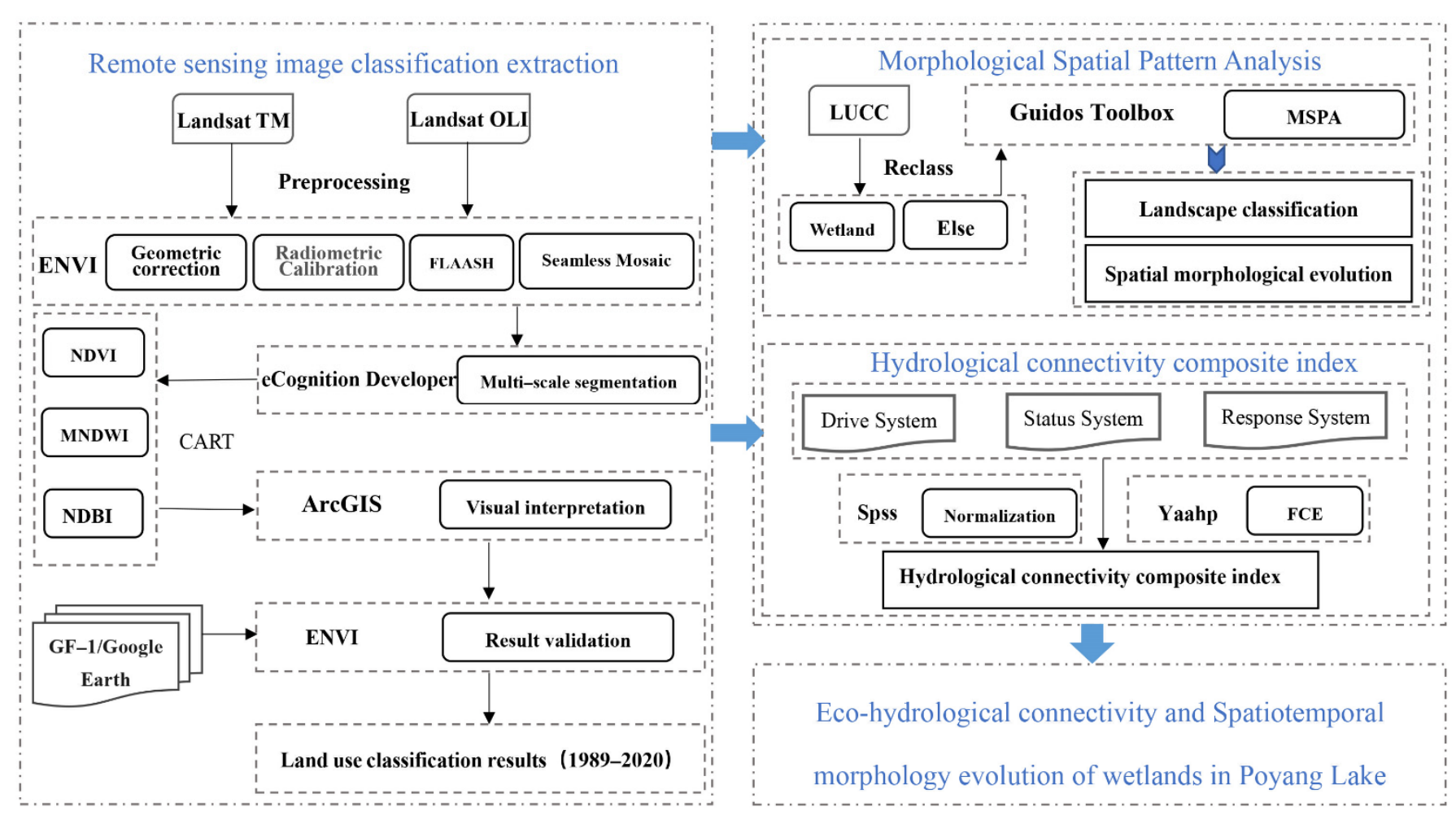

Figure 2. Workflow of this study.

\subsubsection{Remote Sensing Image Classification}

The acquired images were pre-processed with ENVI 5.3 software for geometric correction, radiometric calibration, atmospheric correction, mosaicking, and cropping. Using an object-oriented approach in the eCognition Developer 9.0 software platform, constraint rules were constructed for different land use types using a multiscale segmentation algorithm, supplemented by a modified normalized difference water index (MNDWI), normalized difference vegetation index (NDVI), and normalized difference built-up index (NDBI). A CART decision tree approach was used to classify different landscapes. For preliminary classification results, ArcGIS 10.7 software was used for manual visual interpretation and correction in order to eliminate misclassified objects. Finally, the land use types in the study area were classified into six types: arable land, forest land, grassland, wetland, building land, and unused land.

Of the six extracted land use types, 158 sample points were randomly generated using ENVI5.3 software to ensure that at least 20 points were selected for each land use type, which were combined with 2020 GF-1 satellite images and Google Earth high-spatialresolution images for verification. The interpretation results were analyzed by establishing a classification confusion matrix, selecting a kappa coefficient analysis method, and using a ground-truth sample inspection area in combination with high-resolution images. The results showed that the wetland classification accuracy in all seven phases was above $85 \%$, and the overall kappa coefficient was 0.86 , thus achieving the required accuracy for further analysis.

\subsubsection{Landscape Classification Based on the Morphological Spatial Pattern Analysis Model}

MSPA is a method of image analysis derived from mathematical morphology, based mainly on mathematical binary images. A series of operations are performed on the images to simplify the image data and maintain the basic shape characteristics and structural features for categorization and removal of irrelevant structures [57]. Unlike traditional landscape pattern index methods and landscape connectivity models, MSPA starts from the level of image elements, and not only quickly identifies landscape types that are 
important for landscape connectivity in the study area—such as cores, bridges, loops, and branches-but also assigns a corresponding ecological meaning to each type according to its characteristics and contribution to the flow of information and energy within the study area. This illustrates the changes in functional connectivity in the study area from a morphological perspective (Figure 3). Definitions and characteristics of different MSPA landscape classifications (Table 2) were used to determine their indicative significance in terms of wetland connectivity.

The wetlands were extracted from the classified land use map of the Poyang Lake area in each period, using ArcGIS10.7 as the foreground of the MSPA analysis. Other land use types were used as the background. The size of the image element was $30 \mathrm{~m}$, and an 8-neighborhood algorithm was used. Considering the buffer range between the flat-water period and the flood period of wetland waters, the edge width was set to a size of 2 pixels, i.e., $60 \mathrm{~m}$.
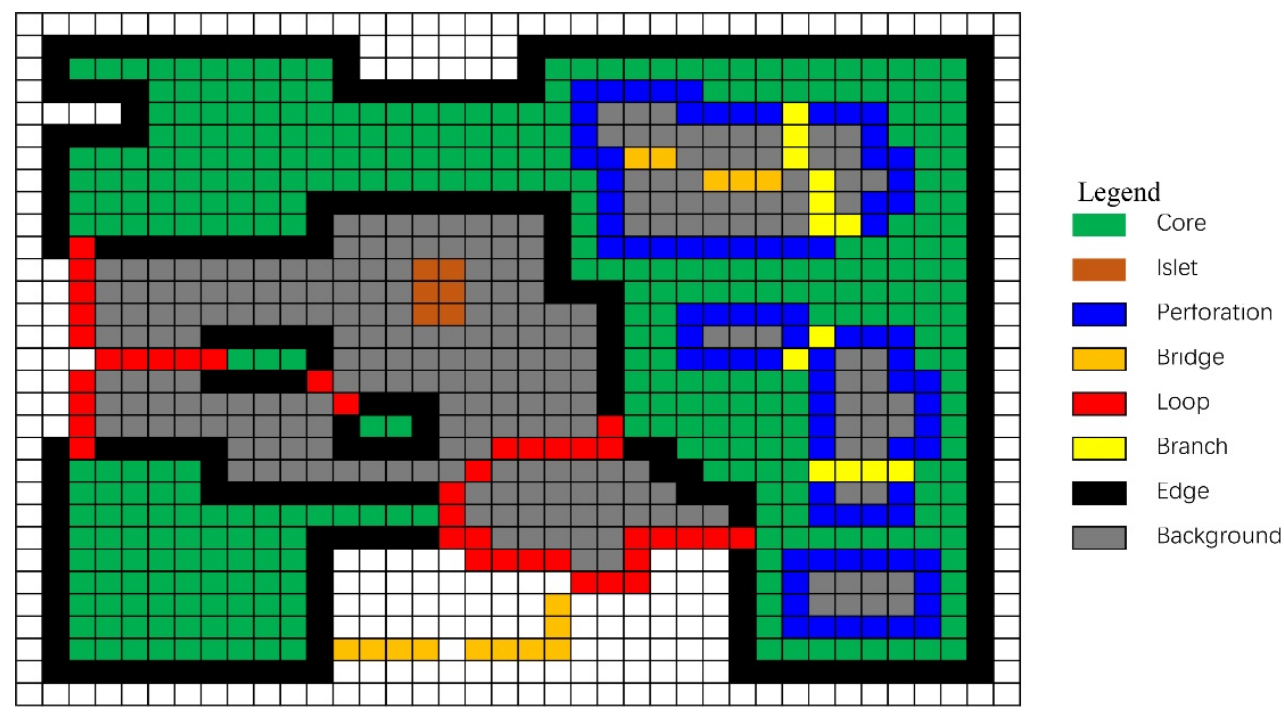

Figure 3. MSPA model classification schematic [36].

Table 2. Types of MSPA landscapes and their meaning.

\begin{tabular}{cc}
\hline Type & Features and Description \\
\hline $\begin{array}{c}\text { Core } \\
\text { Islet }\end{array}$ & $\begin{array}{c}\text { The aggregation of a large number of wetland-like elements with a certain distance from the boundary } \\
\text { A collection of wetland images that are disconnected and aggregated in such small numbers that they cannot be } \\
\text { used as cores }\end{array}$ \\
$\begin{array}{c}\text { Lerforation } \\
\text { Bridge }\end{array}$ & $\begin{array}{c}\text { Lon-core wetland image sets that connect at least two different core classes and exhibit narrow corridor } \\
\text { characteristics }\end{array}$ \\
$\begin{array}{c}\text { Loop } \\
\text { Branch }\end{array}$ & $\begin{array}{c}\text { A narrow collection of wetland-like elements that connects a core class and has the characteristics of a corridor } \\
\text { A collection of wetlands that is not a core class area and is connected at only one end to an edge class, bridge } \\
\text { class, loop class, or perforation class }\end{array}$ \\
Rdge & Refers to the buffer zone between core classes and non-wetlands
\end{tabular}

\subsubsection{Hydrological Connectivity Composite Index}

The proposal and establishment of a hydrological connectivity index system is central to connectivity analysis and evaluation. Current methods for evaluating the hydrological connectivity of wetlands are fragmented, and the evaluation indicators do not sufficiently reflect the overall connectivity of wetland ecosystem structure and function. Therefore, a systematic and comprehensive evaluation method is needed in order to assess the degree of wetland hydrological connectivity at different scales and dimensions, and to consider the degree of dynamic feedback of hydrological connectivity to different driving factors. In 
this study, based on connotation, characteristics, and connectivity, combined with index selection principles, indicators reflecting hydrological connectivity were screened from the perspective of drivers, systems, states, and responses according to the DSR framework model [58]. The final screening indicators were divided into three levels-system level, criterion level, and indicator level - in order to establish a functional evaluation index system of the hydrological connectivity of the basin. The system layer includes the driving force system, the state system, and the response system. The driving force system consists of natural and human factors. The state system is a characteristic of hydrological connectivity in a certain period of time, mainly described and calculated from landscape connectivity. Functional connectivity is achieved by combining the effects of ecological connectivity and hydrodynamic connectivity. Specific indicators based on each criterion layer and screening indicator layer are shown in Table 3.

Table 3. Hydrological connectivity evaluation system for wetlands in the Poyang Lake area.

\begin{tabular}{|c|c|c|c|c|}
\hline System Layer & Guideline Layer & Indicator Layer & Description & Weights \\
\hline \multirow{10}{*}{$\begin{array}{l}\text { Comprehensive } \\
\text { index of } \\
\text { hydrological } \\
\text { connectivity in } \\
\text { the Poyang } \\
\text { Lake area }\end{array}$} & \multirow{4}{*}{ Drive system } & Average annual precipitation (C1) & \multirow{4}{*}{$\begin{array}{c}\text { Direct water source for wetland systems } \\
\text { Affects evaporation of water from } \\
\text { wetlands } \\
\text { Characterizes land use changes } \\
\text { Reflects the degree of interference from } \\
\text { human activities }\end{array}$} & 0.122 \\
\hline & & Vegetation cover $(\mathrm{C} 2)$ & & 0.0775 \\
\hline & & Artificial influence rate (C3) & & 0.0926 \\
\hline & & Population density (C4) & & 0.0413 \\
\hline & \multirow{4}{*}{ Status system } & Landscape division index (C5) & $\begin{array}{l}\text { Characterizes the degree of plaque } \\
\text { separation }\end{array}$ & 0.0495 \\
\hline & & Fragmentation index (C6) & $\begin{array}{l}\text { Characterizes the degree of plaque } \\
\text { fragmentation }\end{array}$ & 0.1419 \\
\hline & & Agglomeration index (C7) & $\begin{array}{c}\text { Characterizes the degree of plaque } \\
\text { aggregation }\end{array}$ & 0.0771 \\
\hline & & Cohesion index $(\mathrm{C} 8)$ & Characterizes natural state connectivity & 0.0648 \\
\hline & \multirow[b]{2}{*}{ Response system } & Wetland habitat area ratio (C9) & Characterizes ecological connectivity & 0.1667 \\
\hline & & Water area rate $(\mathrm{C} 10)$ & $\begin{array}{c}\text { Characterizes lateral hydraulic } \\
\text { connectivity }\end{array}$ & 0.1667 \\
\hline
\end{tabular}

The average annual precipitation (C1) is the average amount of precipitation in the study area in a selected year. Using precipitation data downloaded from the China Meteorological Data Network, the Kriging method [59] was selected for spatial interpolation of raster data for average annual precipitation in the study area.

Vegetation cover (C2), is the vertical projection of vegetation (including leaves, stems, and branches) on the ground as a percentage of the total area. Vegetation cover is commonly used in research on vegetation changes, ecology, soil and water conservation, and climate [60]; it is calculated as follows:

$$
\mathrm{VFC}=(\text { NDVI }- \text { NDVIsoil }) /(\text { NDVIveg }- \text { NDVIsoil })
$$

where NDVIsoil is the NDVI value of an area completely covered by bare soil or no vegetation, and NDVIveg is the NDVI value of an image element completely covered by vegetation, i.e., the NDVI value of a pure vegetation image element. The two values are calculated with formulae as follows:

$$
\begin{aligned}
& \text { NDVIsoil }=(\text { VFCmax } \times \text { NDVImin }- \text { VFCmin } \times \text { NDVImax }) /(\text { VFCmax }- \\
& \text { VFCmin) }
\end{aligned}
$$

$$
\begin{aligned}
\text { NDVIveg }= & ((1-\text { VFCmin }) \times \text { NDVImax }-(1-\text { VFCmax }) \times \\
& \text { NDVImin }) /(\text { VFCmax }- \text { VFCmin })
\end{aligned}
$$


The artificial influence rate (C3) - the proportion of agricultural land and built-up land in the study area-is used to measure the degree of wetland disturbance by land use change; it is calculated as follows:

$$
H_{r}=\frac{F_{i}+C_{i}}{T} \times 100 \%
$$

where $H_{r}$ is the artificial influence rate, $F_{i}$ is the agricultural area in year $i, C_{i}$ is the area of building land in year $i$, and $T$ is the total area of the study area.

Population density (C4), which refers to the number of people per unit of land area, reflects the degree of disturbance by human activities. Population data for each district and county in previous years were obtained from the Statistical Yearbook of Jiangxi Province. ArcGIS and GS+ Version 9 software were used to correlate census data of the study area with the spatial data of the administrative districts based on the administrative district codes. Population density data were calculated via spatial interpolation.

DIVISION (C5) characterizes the dispersion of all patches in a given type of landscape, and also reflects the mixing of different types of patches. As the separation increases, the spatial structure of the landscape becomes discrete and complex, and connectivity decreases [61]:

$$
\operatorname{DIVISION}=\left[1-\sum_{i=1}^{m} \sum_{j=1}^{n}\left(\frac{a_{i j}}{A}\right)^{2}\right]
$$

where $a_{i j}$ is the area of patch $i j$ and $A$ is the total area of the landscape. The value of DIVISION is a non-negative number less than one: it is zero when the whole landscape consists of only one patch, and it is one when this type of landscape contains only one patch with area equivalent to a raster. DIVISION approaches 1 when the area weight and patch size decrease in this patch type.

The fragmentation index (C6) indicates the number of patches calculated based on the weighted average area of a certain type of patch in the entire landscape, and is used to observe landscape fragmentation; the higher its value, the greater the landscape fragmentation [62]:

$$
F N=\left(N_{\mathrm{p}}-1\right) / N_{\mathrm{c}}
$$

where $F N$ is the landscape fragmentation index of the whole study area, $N_{\mathrm{c}}$ is the total area of the landscape, and $N_{p}$ is the total number of different types of patches in the landscape.

The agglomeration index (C7) shows the ratio of the number of similar neighbors to the maximum number of each neighboring landscape type, when the types are maximally aggregated into patches. AI is usually multiplied by 100 to express a percentage; it is suitable for exploring the degree of non-randomness or aggregation of different types of patches [63]:

$$
\mathrm{AI}=\left[\frac{g_{i}}{\operatorname{maxg}_{i}}\right] \times 100
$$

where $g_{i}$ is the number of nodes between the image elements of the patch type $I$, and $\operatorname{maxg}_{i}$ is the maximum number of nodes between the image elements of the patch type $i$. AI is the aggregation index, which is equal to the value of $g$ divided by the maximum value of $g$ when that type is maximally aggregated together.

COHESION (C8), the cohesion index, is used to measure the natural state connectivity of a patch type. As patch distribution becomes more aggregated and natural connectivity increases, the patch cohesion index increases; the value of this index tends towards zero when the proportion of the patch type in the landscape decreases, reducing connectivity [64]:

$$
\text { COHESION }=\left[1-\frac{\sum_{i=1}^{m} \sum_{j=1}^{n} p_{i j}}{\sum_{i=1}^{m} \sum_{j=1}^{n} p_{i j} \sqrt{a_{i j}}}\right]\left[1-\frac{1}{\sqrt{A}}\right]^{-1} \times 100
$$


where $m$ is the sum of landscape types, $n$ is the number of landscape patches of type $i, p_{i j}$ is the perimeter of patch $i j$, and $A$ is the size of the whole landscape.

Habitat quality (C9) represents the living space of individual organisms, species, and communities. Habitat quality reflects the ability of an ecosystem to provide appropriate conditions for species survival. The InVEST habitat quality model provides a choice of threat sources for assessing the habitat quality of wetlands by analyzing the threat level, threat distance, and relative impact to other LULC types for each grid [65]:

$$
Q_{x j}=H_{j}\left[1-\frac{D_{x j}^{z}}{D_{x j}^{z}+K^{z}}\right]
$$

where $Q_{x j}$ is the habitat quality in the grid cell $x$ with LULC $j, H_{j}$ is the habitat suitability on gridcell $x$ for LULC $j, D_{x j}$ is the extent of habitat degradation in the grid cell $x$ with LULC $j$, and $K$ is the half-saturation constant.

The water area ratio (C10) is the ratio of water body area to the area of a sub-basin; it is used to characterize the lateral hydrological connectivity, and is calculated as follows:

$$
W_{r}=\frac{A_{i}}{T} \times 100 \%
$$

where $W_{r}$ refers to the water area rate, $A_{i}$ refers to the water body area in year $I$, and $T$ refers to the sub-basin area.

After using the above formulae and methods to calculate the index system, it was necessary to establish corresponding evaluation criteria, i.e., to assign weights to each index, because each element has different mechanisms and degrees of influence on the wetland hydrological connectivity.

In a comprehensive multi-indicator evaluation method, the reliability of the assessment is directly affected by the appropriateness of the indicator weights, and a reasonable assignment of weights is the key to quantitative evaluation. The combination of subjective and objective assignment methods, such as fuzzy comprehensive evaluation, can reflect both the subjective will of the decision makers and the objective reality of the decision problem [44,66-68]. Therefore, in this study, the fuzzy hierarchical analysis method was used to assign the index system weights.

After calculating the weights using fuzzy hierarchical analysis, the different judgments of many experts were further summarized by group judgment theory, and the final weights of each index were obtained by calculating the confidence degree of each expert. The weights of each index at each level are shown in Table 3.

The original indicators selected in the evaluation process represent different quantitative attributes, sources, and units of measurement, and are not mutually comparable. In the process of overlaying the spatial data on each topic, it is necessary to first standardize the data for each topic in order to eliminate the impact of each indicator due to the measurement scale and unit, instead of directly using the original data on each topic for simple mathematical operations [69-71]. In this study, the "extreme difference method" was chosen to standardize the data as follows:

Positivized indicator treatment formula:

$$
Z_{i}=\frac{X_{i}-X_{\min }}{X_{\max }-X_{\min }}
$$

Negativized indicator treatment formula:

$$
Z_{i}=\frac{X_{\max }-X_{i}}{X_{\max }-X_{\min }}
$$

where $Z_{i}$ is the value of the index after dimensionless processing, $X_{i}$ is the actual value of the index before standardization, $X_{\max }$ is the maximum index value in the evaluation region, and $X_{\min }$ is the minimum value [72]. 
After assigning and standardizing each index, the hydrological connectivity index for the Poyang Lake area was obtained as follows:

$$
\begin{aligned}
H C C I=\mathrm{C} 1 \times 0.122 & +\mathrm{C} 2 \times 0.0775+\mathrm{C} 3 \times 0.0926+\mathrm{C} 4 \times 0.0413 \\
& +\mathrm{C} 5 \times 0.0495+\mathrm{C} 6 \times 0.1419+\mathrm{C} 7 \times 0.0771 \\
& +\mathrm{C} 8 \times 0.0648+\mathrm{C} 9 \times 0.1667+\mathrm{C} 10 \times 0.1667
\end{aligned}
$$

\section{Results}

3.1. Landscape Type Changes Based on MSPA from 1989 to 2020

3.1.1. Landscape Type Evolution Characteristics

After MSPA analysis, we obtained a functional type pattern of wetland hydrological connectivity in the Poyang Lake area (Figure 4) along with a statistical table of changes in area and numbers of patches (Table 4). In general, the wetland landscape changes in the Poyang Lake area were more dramatic, i.e., they first decreased, and then increased, and the changes in different landscape types were clear.

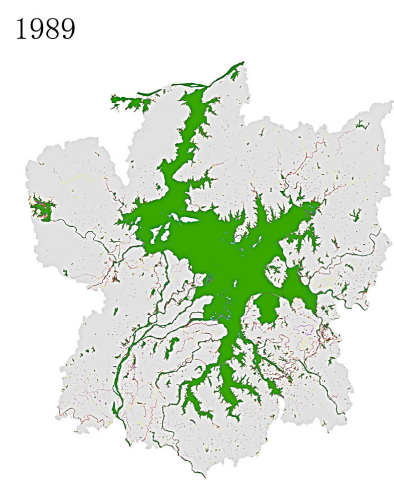

1995

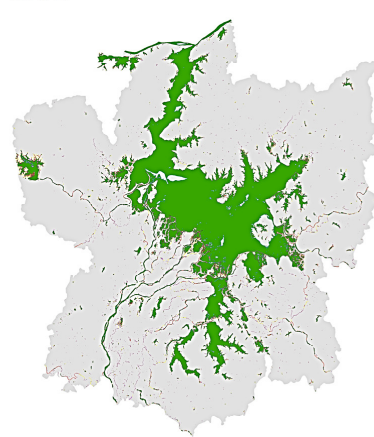

2015

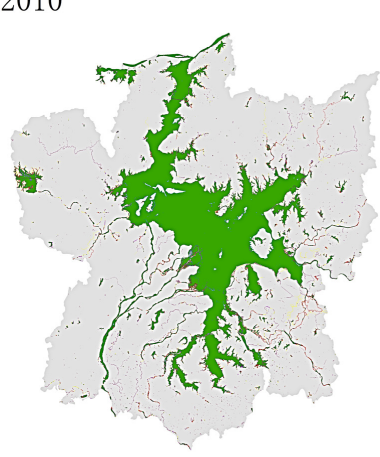

2000

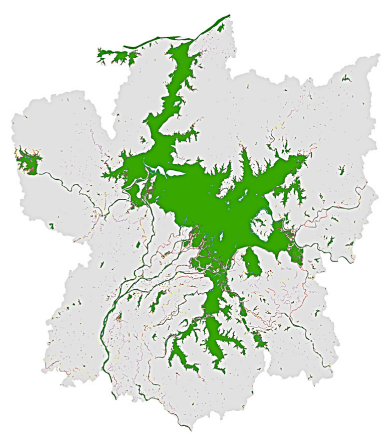

2020
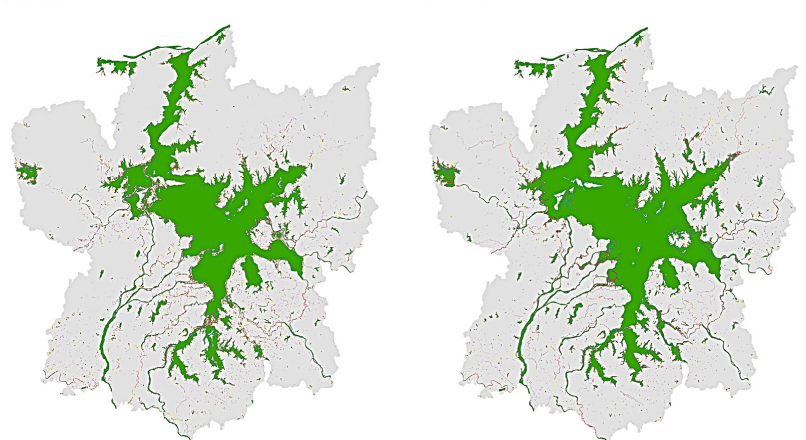

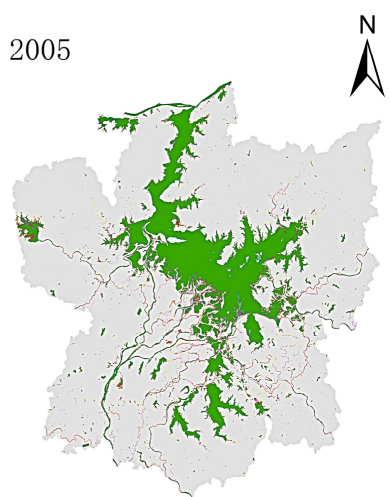

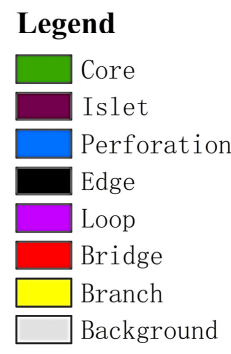

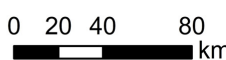

Figure 4. Distribution maps of MSPA types in the Poyang Lake area from 1989 to 2020.

(1) Core wetlands, edge wetlands, and foregrounds had similar area change trends from 1989 to 2020, all decreasing in the first period and increasing after reaching the lowest point in 2005; the ratio of core areas to foreground areas decreased and then increased from 1989 to 2020. From 1989 to 2005, the wetland landscape was fragmented, and the landscape connectivity decreased, while from 2005 to 2020, the core area increased, and the landscape connectivity was higher. Material and energy exchanges between patches were more frequent, which favored maintaining the stability and biodiversity of wetland ecosystems. Both spatially and in terms of area, the core wetlands exhibited gradual fragmentation followed by recovery from 1989 to 2020 (Figure 5C);

(2) Branches, bridges, and loops all play the role of corridors in the wetland connectivity functions. The contribution of these three types of wetlands to hydrological connectivity was greatest for bridging wetlands, followed by branching wetlands, and least for loop wetlands. The peaks and troughs of bridge and loop wetland areas 
were practically the same in the period from 1989 to 2020, and both had W-shaped trends, meaning that there were more small rivers in the Poyang Lake area, and they easily disappeared and reappeared due to natural factors. The peak value of branch wetlands appeared in 2015, while the trough value appeared in 2010, with constant fluctuation (Figure 5A);

(3) From 1989 to 2020, the ratio of the islet wetland areas to the foreground wetland areas decreased, then increased, then decreased again. The presence of too many islets increased the number of patches and led to a decrease in the overall connectivity. The area of perforation wetlands was more stable, and was the smallest of the foreground wetlands; the largest was less than $50 \mathrm{~km}^{2}$, and had little impact on the wetland hydrological connectivity (Figure 5B).

Table 4. Area and number of patches in each MSPA class in the wetlands of the Poyang Lake area from 1989 to 2020.

\begin{tabular}{|c|c|c|c|c|c|c|c|c|c|}
\hline & Type & Core & Islet & Perforation & Edge & Loop & Bridge & Branch & Foreground \\
\hline \multirow{2}{*}{1989} & Area $/ \mathrm{km}^{2}$ & 3840.4485 & 111.3966 & 38.5245 & 415.7019 & 42.2577 & 99.8631 & 128.1933 & 4676.386 \\
\hline & $\begin{array}{l}\text { Number } \\
\text { of patches }\end{array}$ & $4,267,165$ & 123,774 & 42,805 & 461,891 & 46,953 & 110,959 & 142,437 & $5,195,984$ \\
\hline \multirow{2}{*}{1995} & Area $/ \mathrm{km}^{2}$ & 3271.0707 & 76.6548 & 41.886 & 391.0059 & 16.1847 & 57.9402 & 106.1811 & 3960.923 \\
\hline & $\begin{array}{l}\text { Number } \\
\text { of patches }\end{array}$ & $3,634,523$ & 85,172 & 46,540 & 434,451 & 17,983 & 64,378 & 117,979 & $4,401,026$ \\
\hline \multirow{2}{*}{2000} & Area $/ \mathrm{km}^{2}$ & 3323.4903 & 87.7392 & 35.2872 & 394.6068 & 11.583 & 67.5144 & 109.2087 & 4029.43 \\
\hline & $\begin{array}{l}\text { Number } \\
\text { of patches }\end{array}$ & $3,692,767$ & 97,488 & 39,208 & 438,452 & 12,870 & 75,016 & 121,343 & $4,477,144$ \\
\hline \multirow{2}{*}{2005} & Area $/ \mathrm{km}^{2}$ & 2859.9669 & 82.2573 & 28.7424 & 327.8358 & 44.1873 & 120.9573 & 118.4742 & 3582.421 \\
\hline & $\begin{array}{l}\text { Number } \\
\text { of patches }\end{array}$ & $3,177,741$ & 91,397 & 31,936 & 492,379 & 49,097 & 134,397 & 131,638 & $3,980,468$ \\
\hline \multirow{2}{*}{2010} & Area $/ \mathrm{km}^{2}$ & 3528.0117 & 84.1986 & 39.2841 & 443.1411 & 55.0026 & 92.8287 & 94.0311 & 4336.498 \\
\hline & $\begin{array}{l}\text { Number } \\
\text { of patches }\end{array}$ & $3,920,013$ & 93,554 & 43,649 & 364,262 & 61,114 & 103,143 & 104,479 & $4,818,331$ \\
\hline \multirow{2}{*}{2015} & Area $/ \mathrm{km}^{2}$ & 3297.7746 & 136.9098 & 24.7374 & 424.9269 & 18.7002 & 88.3071 & 156.0105 & 4147.367 \\
\hline & $\begin{array}{l}\text { Number } \\
\text { of patches }\end{array}$ & $3,664,194$ & 152,122 & 27,486 & 472,141 & 20,778 & 98,119 & 173,345 & $4,608,185$ \\
\hline \multirow{2}{*}{2020} & Area $/ \mathrm{km}^{2}$ & 3823.5933 & 83.1024 & 41.2146 & 404.0793 & 49.3947 & 89.3385 & 105.9831 & 4596.706 \\
\hline & $\begin{array}{l}\text { Number } \\
\text { of patches }\end{array}$ & $4,248,437$ & 92,336 & 45,794 & 448,977 & 54,883 & 99,265 & 117,759 & $5,107,451$ \\
\hline
\end{tabular}

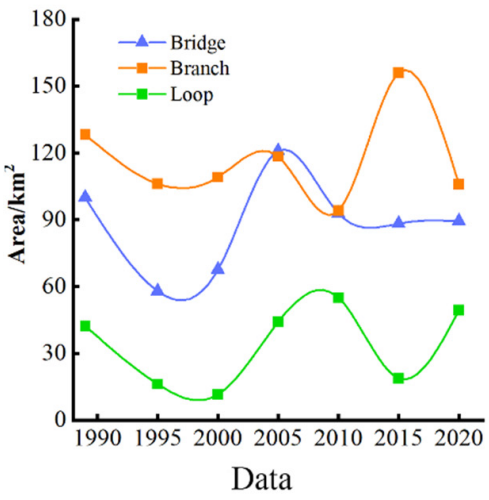

(A)

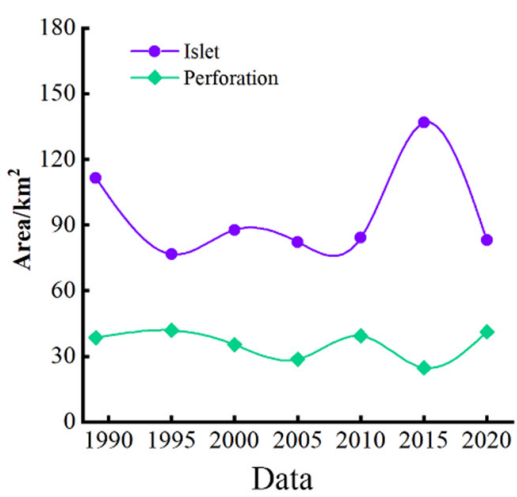

(B)

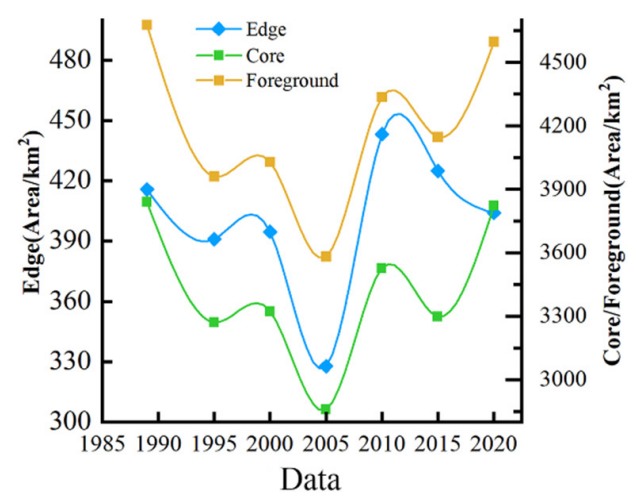

(C)

Figure 5. Changes in the landscape types in the Poyang Lake area based on MSPA. (A) Bridge Branch and Loop Landscape type evolution; (B) Islet and Perforation Landscape type evolution; (C) Edge Core and Foreground Landscape type evolution.

\subsubsection{Landscape Type Conversion Characteristics}

The conversion of wetland landscape types in the Poyang Lake area from 1989 to 2020 is shown in Table 5. Over 31 years, $320.60 \mathrm{~km}^{2}$ of core wetlands was converted to other types, and most were converted to non-wetlands $\left(148.59 \mathrm{~km}^{2}\right)$, followed by edge 
wetlands $\left(114.57 \mathrm{~km}^{2}\right)$. Approximately $299.87 \mathrm{~km}^{2}$ was converted to core wetlands, with most converted from non-wetlands $\left(163.55 \mathrm{~km}^{2}\right)$, followed by edge wetlands $\left(87.07 \mathrm{~km}^{2}\right)$. The net change in the core wetland area was $-20.73 \mathrm{~km}^{2}$.

Table 5. Landscape type conversion matrix in the Poyang Lake area from 1989 to 2020 (unit: $\mathrm{km}^{2}$ ).

\begin{tabular}{cccccccccc}
\hline & \multicolumn{8}{c}{2020} \\
\cline { 3 - 8 } & & Core & Edge & Perforation & Branch & Islet & Loop & Bridge & $\begin{array}{c}\text { Non- } \\
\text { Wetlands }\end{array}$ \\
\cline { 3 - 9 } & Core & 3519.2385 & 114.5736 & 13.2012 & 7.0272 & 2.8665 & 14.8239 & 19.5174 & 148.59 \\
1989 & 87.0669 & 128.6316 & 3.6612 & 12.6351 & 4.6035 & 10.5525 & 13.9122 & 154.5966 \\
& Edge & 17.6175 & 2.5137 & 10.8675 & 0.3249 & 0.045 & 0.9846 & 0.4689 & 5.7024 \\
& Perforation & 6.3666 & 9.981 & 0.5292 & 15.9417 & 5.5638 & 2.0016 & 4.6791 & 83.0799 \\
& Branch & 2.4066 & 2.0727 & 0.0801 & 2.4921 & 14.5152 & 0.3879 & 1.1322 & 88.2603 \\
& Islet & 10.7991 & 5.7339 & 1.134 & 1.4436 & 0.8667 & 2.1636 & 1.2213 & 18.8622 \\
& Loop & 12.0609 & 10.3239 & 0.5436 & 5.3721 & 3.4722 & 1.4508 & 12.8961 & 53.7021 \\
& Bridge & 163.5525 & 129.8268 & 11.1771 & 60.6276 & 51.0921 & 16.9731 & 35.4402 & $15,172.5681$ \\
\hline
\end{tabular}

During the study period, the landscape types in the Poyang Lake area also changed among edge wetlands and non-wetlands. Approximately $287.01 \mathrm{~km}^{2}$ of marginal wetland area was converted to other types, with most converted to non-wetlands $\left(154.60 \mathrm{~km}^{2}\right)$, followed by core wetlands $\left(87.07 \mathrm{~km}^{2}\right)$. Approximately $114.57 \mathrm{~km}^{2}$ and $129.83 \mathrm{~km}^{2}$ of core wetland and non-wetland areas were converted to marginal wetlands, respectively. The net change in marginal wetland area was $-42.61 \mathrm{~km}^{2}$. For non-wetlands, which were the most changed landscape type in the study area, a total of $468.69 \mathrm{~km}^{2}$ was converted to other types during the 31-year period. The largest type of non-wetland conversion was to core wetlands and edge wetlands, with $163.55 \mathrm{~km}^{2}$ and $129.83 \mathrm{~km}^{2}$, respectively. However, the non-wetland area increased by $84.10 \mathrm{~km}^{2}$ during the study period, indicating that the overall area of wetlands in the Poyang Lake area decreased. Other types of wetland landscapes-such as islets, perforations, bridges, loops, and branches-accounted for a smaller proportion, and the overall change during the study period was not significant.

In general, the seven types of wetland landscapes mostly coverted to non-wetlands during the study period, mainly through the core areas, edge areas, and non-wetland areas, while the other types converted to similar areas to one another.

The characteristics of wetland landscape conversions varied in different time periods (Figure 6). Combined with changes in landscape type characteristics from 1989 to 2005 (Figure 6a), the wetland landscape was mainly converted out, with the largest transitions from the core wetlands to the non-wetlands, followed by conversions within the wetland landscape. From 1989 to 2005, the core wetlands were partially converted into three corridor wetlands; meanwhile, as the core wetland area declined, the three corridor wetlands types decreased and then increased. However, the increase in corridor wetlands did not lead to an increase in connectivity, due to the dominant role of the core wetlands. In addition to the core wetlands, a larger proportion of other types of wetlands-such as edge, branch, and islet wetlands-were converted to non-wetlands. These conversions illustrate that the overall wetland area decreased along with the overall connectivity of the wetland landscape from 1989 to 2005. From 2005 to 2020, the opposite trend was observed in relation to the previous period, as exemplified by a predominant conversion of wetland landscapes. The largest conversion area during this period was from the non-wetlands to the core wetlands, followed by the non-wetlands to other types of wetlands. While the area of the core wetlands increased, the area of the three types of corridor wetlands also increased, which played an auxiliary role in improving hydrological connectivity (Figure $6 \mathrm{~b}$ ). Within the wetland landscape, the conversion of other small wetland patches into core wetlands showed reduced fragmentation and increased hydrological connectivity. 


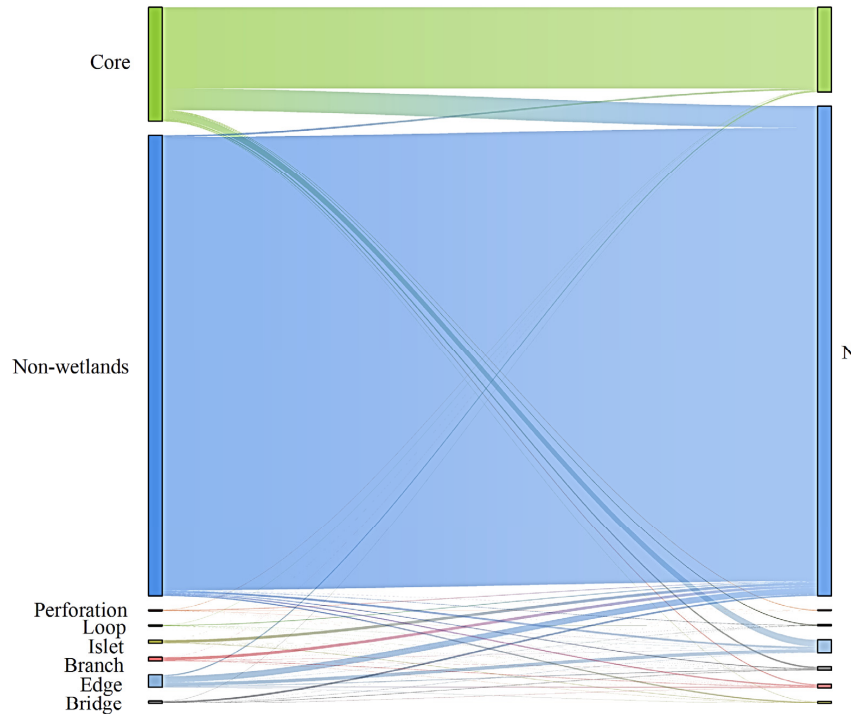

1989 (a)

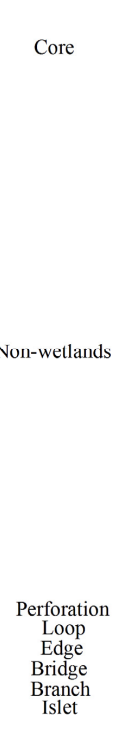

2005

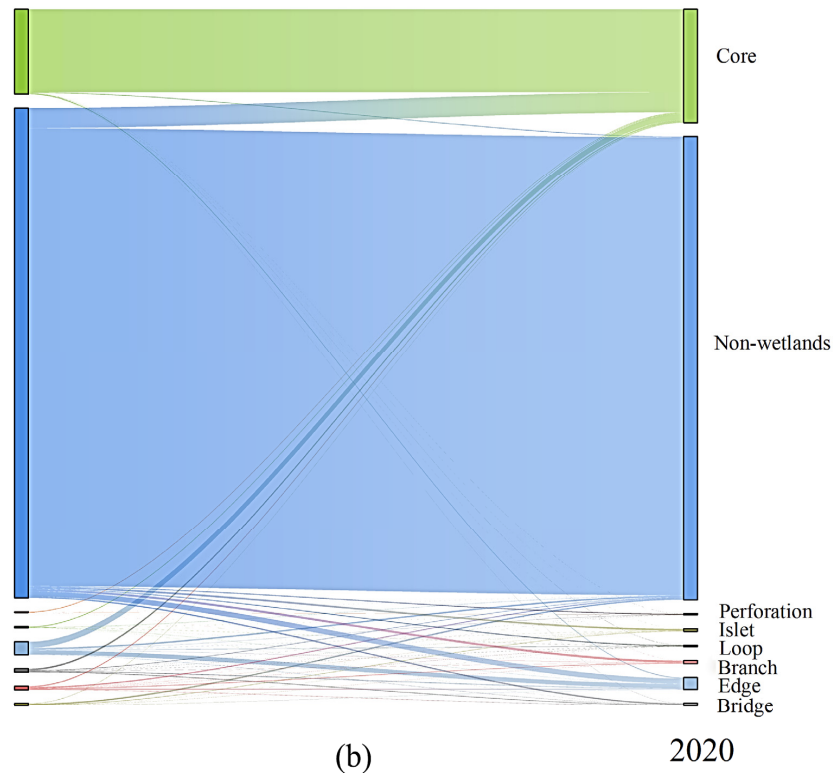

(b)

2020

Figure 6. MSPA-based landscape type conversion in the Poyang Lake area: (a) conversions from 1989 to 2005; (b) conversions from 2005 to 2020.

\subsection{Evolution of Hydrological Connectivity in the Poyang Lake Area}

The eco-hydrological connectivity of wetlands in the Poyang Lake area first decreased and then increased during the study period, and the overall trend was W-shaped (Figure 5). From 1989 to 2005, the hydrological connectivity of the wetlands fluctuated and decreased, and from 2005 to 2020 it increased significantly-similar to the changes in the core wetlands as analyzed by MSPA. The lowest value occurred in 2005. Changes in the core wetlands played a dominant role in the evolution of hydrological connectivity. The hydrological connectivity composite index (HCCI) revealed the wetland hydrological connectivity in the Poyang Lake area in a more intuitive and quantitative way.

From a time perspective, in 1989, the C10 indicator contributed the most to the hydrological connectivity index, meaning that at that time the water area rate of the Poyang Lake area was higher, the coverage of water bodies was larger, the wetland landscape was more complete, and hydrological connectivity was higher. By 2005, all indices except C9 were low, and the land use structure in the Poyang Lake area was influx-adjusted, leading to a reduction in wetland area. The core wetlands were converted to non-wetlands, the edge wetlands were eroded by the non-wetlands, and various corridor wetlands were refined. This increased the fragmentation of the wetland landscape, producing scattered wetland patches and reduced hydrological connectivity in the whole area (Figure $7 \mathrm{~d}$ ). In 2020, precipitation increased compared to the previous period; the wetland area had expanded, water surfaces had covered a wide area, and the wetland habitat quality had improved. The increase in the core wetlands reduced the wetland fragmentation in this period; thus, the landscape integrity was high, and the wetland hydrological connectivity reached its highest level in the study period. However, disturbance by human activitiessuch as changes in wetlands-also strengthened during this period, and vegetation cover decreased with economic development, increasing population density, and expanding built-up urban areas (Figure 7g). Overall, the eco-hydrological connectivity of wetlands first deteriorated, and then improved, over the course of the study period.

$\mathrm{C} 5, \mathrm{C} 6$, and HCCI had significant negative correlations. When the degree of landscape separation (C5) and landscape fragmentation (C6) increased, the spatial structure of the landscape became discrete and complex, and the hydrological connectivity decreased. C10 and HCCI had a significant positive correlation, i.e., the wetland area rate (C10) contributed positively to the hydrological connectivity, as a higher rate meant higher wetland landscape integrity and higher overall hydrological connectivity (Figure 8). 


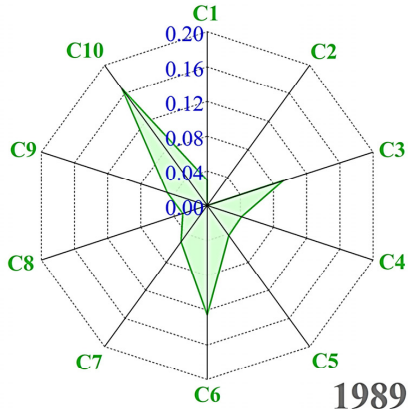

(a)

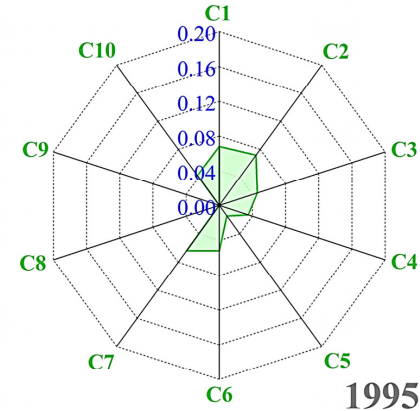

(b)

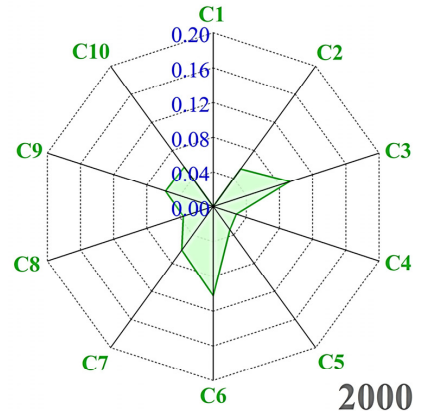

(c)
2000

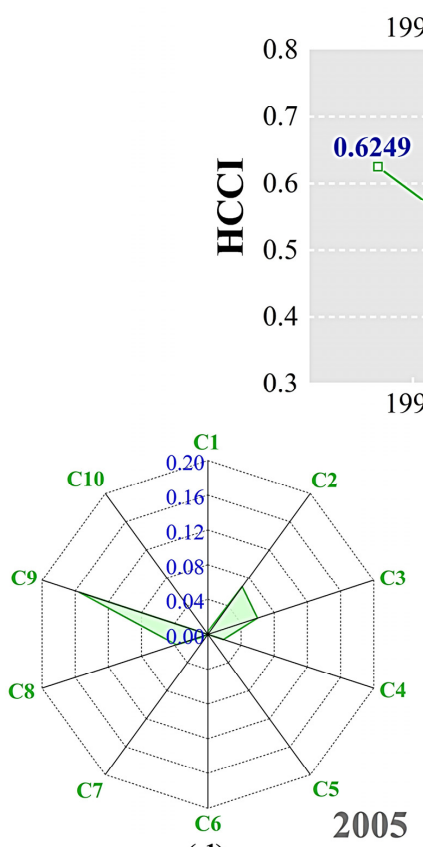

(d)
2005

1995

2000

2005

1995

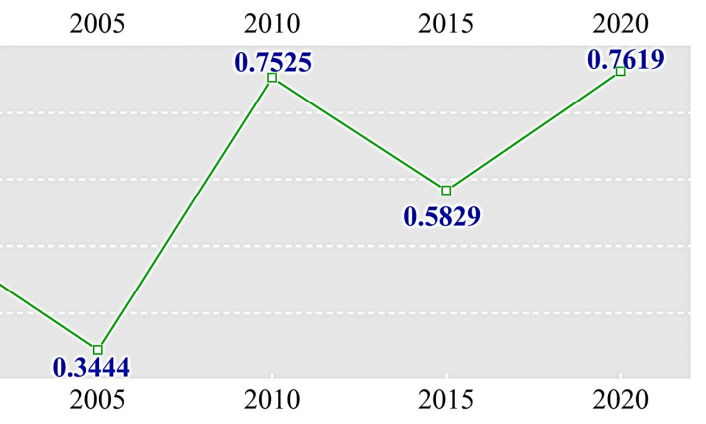

2015

2020

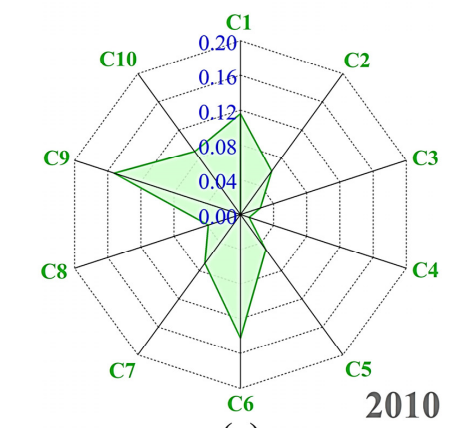

(e)

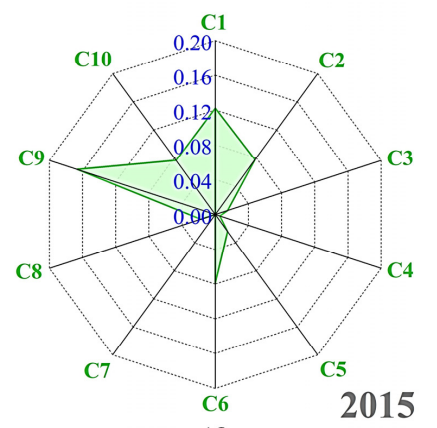

(f)

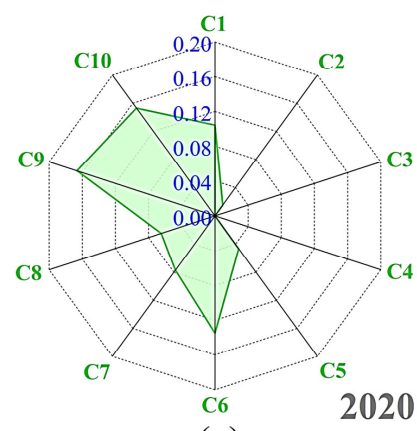

(g)

Figure 7. Hydrological connectivity composite index and radar maps for each index: (a-g) the scores of 10 indicators for 7 periods from 1989 to 2020 .

\subsection{Spatial and Temporal Evolution of Hydrological Connectivity: "Receding-Restoring"}

According to the hydrological connectivity index and the results of the MSPA model, the spatial and temporal evolution of hydrological connectivity in the Poyang Lake area from 1989 to 2020 is divided into two stages: receding and restoring.

Hydrological connectivity receding phase (1989-2005): (1) the area of each MSPA type gradually decreased, first with receding fine patches, and then larger core patches receded after splitting into small core patches or branches, islands, and other types; (2) the main types of receding and splitting wetlands were the core areas, and morphological transformation to fragmentation and elongation occurred; (3) receding of fine core patches was accompanied by a decrease in branches, bridges, atolls, islets and other types of wetlands, which increased again after the core wetland patches were split; (4) during the process of reducing the core wetland area, the proportion of edge wetlands in the foreground continued to increase, reflecting the irregularity of core patches; (5) the number of perforations was proportional to the area and the core wetland area; and (6) the hydrological connectivity index fluctuated and decreased, the wetland area decreased, the landscape fragmentation intensified, and the impact of human activities on the wetland area increased.

Hydrological connectivity restoration phase (2005-2020): (1) the core area gradually increased in size, the number of core wetlands gradually increased, the proportion of foreground wetlands also gradually increased, and the morphology changed from elongated to saturated; (2) the loop wetlands were gradually subsumed by saturated core 
patches, and branch wetlands gradually transformed into bridge wetlands; (3) the area and number of islet areas decreased during the first stage of restoration, and increased in the later stage; (4) perforation and edge wetlands increased-the proportion of the former in the foreground gradually increased, and the proportion of the latter in the foreground gradually decreased; (5) wetland areas increased through the conversion of the non-wetlands to wetland landscapes; and (6) the composite index of wetland hydrological connectivity increased, reaching a maximum by 2020 - the water area rate increased, the wetland habitat quality improved, the wetland landscape integrity was strengthened, and fragmentation improved.

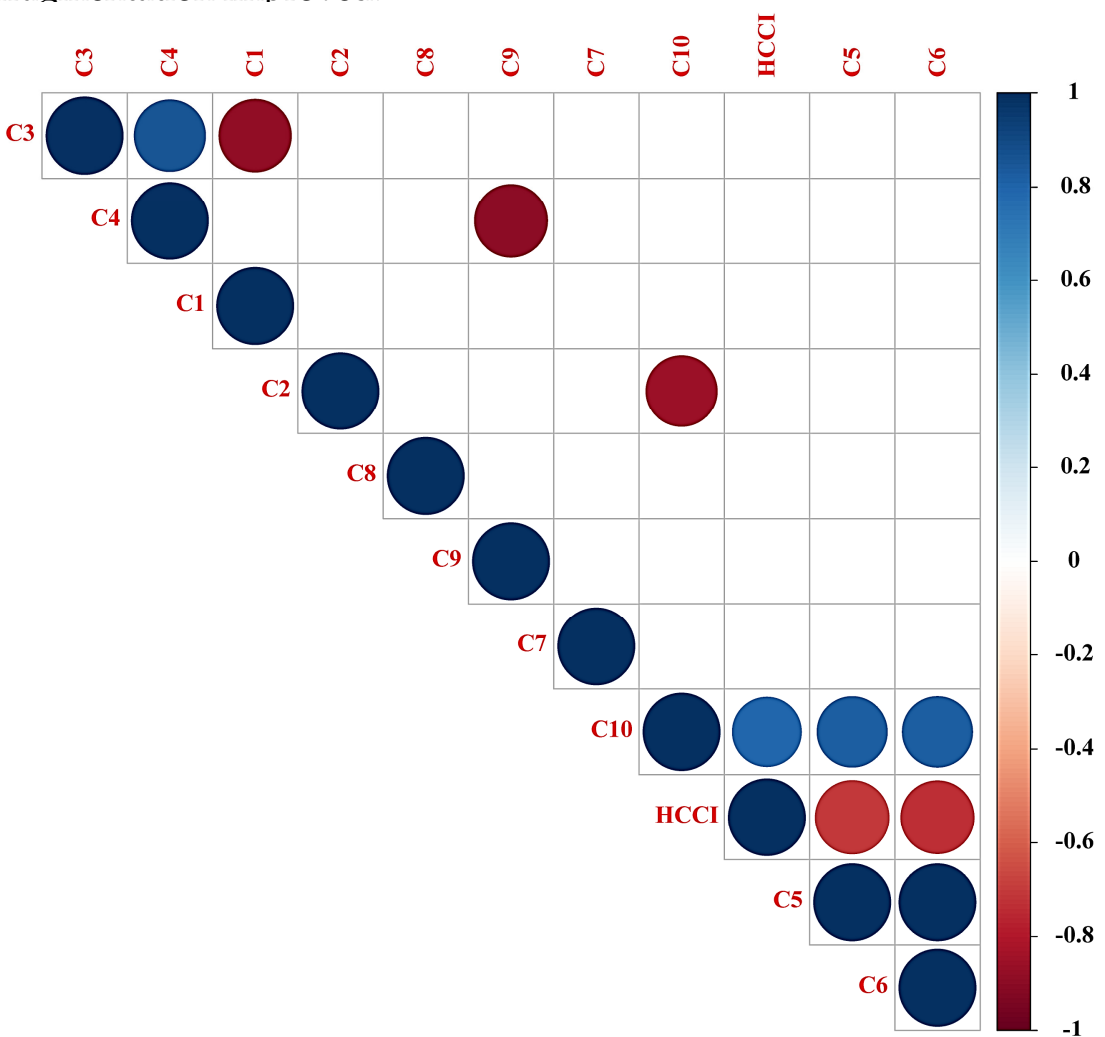

Figure 8. Pearson's correlation between different indicators and the composite index of hydrological connectivity.

\section{Discussion}

\subsection{Influence of Choice of Different Scales on MSPA Results}

MSPA is very sensitive to the scale of the landscape, and a reasonable choice of image element size and edge width is necessary in order to obtain an accurate distribution of the spatial pattern of landscape types. Wickham et al. [73] stated that granularity is the area of the smallest identifiable unit in a landscape, i.e., the size of an image element. The landscape structure is formed by the spatial arrangement and combination of different forms and the number of landscape elements, which is easily influenced by granularity [33]. The edge width collection defines the width or thickness of the non-core class in pixels. The actual distance corresponds to the number of edge pixels multiplied by the pixel resolution of the data. Yu et al. [74] concluded that landscape types obtained on the basis of MSPA have an obvious scale and edge effect through the study of the urban green infrastructure network in Nanjing, and that the scale effect has smaller impact on landscape types, while the edge effect is more obvious. The extent and degree of edge effects vary depending on the nature of the landscape, the study area, and the shape of the patches, and increasing the edge width leads to a decrease in the core area of the landscape type and an increase in the non-core elements; these factors affect the results of MSPA analysis [40,75]. 
To analyze the morphological spatial pattern and compare changes in wetland structure in the study area at different grain sizes, we used Guidos Toolbox 3.0 software, set structural elements to 8 neighborhoods, set the edge width parameter to 2 (corresponding to $60 \mathrm{~m}$ geospatial width), and selected 3 types of binary raster files with resolutions of $30 \mathrm{~m} \times 30 \mathrm{~m}, 60 \mathrm{~m} \times 60 \mathrm{~m}$, and $120 \mathrm{~m} \times 120 \mathrm{~m}$. Changes in landscape structure at different grain sizes were compared. Similarly, to compare the appropriate edge widths, we used binary raster data at a uniform $30 \mathrm{~m} \times 30 \mathrm{~m}$ resolution. To explore the influence of the change in edge width on the landscape structure when the geospatial widths were $30 \mathrm{~m}$, $60 \mathrm{~m}$, and $120 \mathrm{~m}$, the edge width parameters were set to 1,2, and 4, respectively, and the spatial pattern analysis of the wetland landscape morphology was performed.

From Table 6, we can see that the largest change in the wetland landscape with increasing particle size (constant edge width of $60 \mathrm{~m}$ ) occurred in the core wetlands, indicating that the increase in particle size reduced the core landscape area. In terms of the proportion of wetland landscape areas occupied by each type, the core wetland areas have been steadily declining, but other types have increased, indicating that increasing particle size has transformed some core wetland landscapes into edge wetlands, bridge wetlands, and loop wetlands, while some smaller core area patches have been transformed into islets, or have been completely eliminated. For comparison, we found that landscape classifications obtained via MSPA with different particle sizes were very unstable, and the core area wetlands were significantly reduced.

At a constant grain size $(30 \mathrm{~m} \times 30 \mathrm{~m})$ with increasing edge width, the core wetlands remained the dominant landscape type in the study area (Figure 9). A comparison in terms of patch area revealed that the proportion of the core area patches decreased, while the proportion of islets, edges, bridges, and branches increased (Table 7). This was mainly due to an increase in edge width, which increased the minimum core area size and caused an increase in the width of the non-core area elements. This reduced the number of core area pixels, resulting in a loss of core area which, in turn, caused an increase in other MSPA landscape types.

Table 6. Area of each MSPA type in different resolutions, and proportion of wetland landscape area (edge width $60 \mathrm{~m}$ ).

\begin{tabular}{|c|c|c|c|c|c|c|}
\hline \multirow[b]{2}{*}{ Landscape Type } & \multicolumn{2}{|c|}{ Pixel $30 \mathrm{~m} \times 30 \mathrm{~m}$} & \multicolumn{2}{|c|}{ Pixel $60 \mathrm{~m} \times 60 \mathrm{~m}$} & \multicolumn{2}{|c|}{ Pixel $120 \mathrm{~m} \times 120 \mathrm{~m}$} \\
\hline & Area/ha & $\begin{array}{l}\text { Percentage of } \\
\text { Wetlands (\%) }\end{array}$ & Area/ha & $\begin{array}{l}\text { Percentage of } \\
\text { Wetlands (\%) }\end{array}$ & Area/ha & $\begin{array}{l}\text { Percentage of } \\
\text { Wetlands (\%) }\end{array}$ \\
\hline Core & $413,147.61$ & 89.88 & $351,956.88$ & 74.91 & $307,913.76$ & 65.52 \\
\hline Islet & 1867.23 & 0.41 & $16,064.28$ & 3.42 & $27,466.56$ & 5.84 \\
\hline Perforation & 5289.48 & 1.15 & 4834.08 & 1.03 & 5495.04 & 1.17 \\
\hline Edge & $29,172.42$ & 6.35 & $45,729.72$ & 9.73 & $44,619.84$ & 9.49 \\
\hline Loop & 1357.92 & 0.30 & $10,293.84$ & 2.19 & $19,362.24$ & 4.12 \\
\hline Bridge & 2458.71 & 0.53 & $22,296.24$ & 4.75 & $38,867.04$ & 8.27 \\
\hline Branch & 6377.22 & 1.39 & $18,667.80$ & 3.97 & $26,212.32$ & 5.58 \\
\hline
\end{tabular}

Table 7. Area of each MSPA type at different edge widths, and proportion of wetland landscape area (at a grain size of $30 \mathrm{~m}$ ).

\begin{tabular}{|c|c|c|c|c|c|c|}
\hline \multirow[b]{2}{*}{ Landscape Type } & \multicolumn{2}{|c|}{30 Edge with $30 \mathrm{~m}$} & \multicolumn{2}{|c|}{60 Edge with $60 \mathrm{~m}$} & \multicolumn{2}{|c|}{120 Edge with $120 \mathrm{~m}$} \\
\hline & Area/ha & $\begin{array}{l}\text { Percentage of } \\
\text { Wetlands }(\%)\end{array}$ & Area/ha & $\begin{array}{l}\text { Percentage of } \\
\text { Wetlands (\%) }\end{array}$ & Area/ha & $\begin{array}{l}\text { Percentage of } \\
\text { Wetlands (\%) }\end{array}$ \\
\hline Core & $413,147.61$ & 89.88 & $382,359.33$ & 83.18 & $352,324.26$ & 76.65 \\
\hline Islet & 1867.23 & 0.41 & 8310.24 & 1.81 & $21,616.47$ & 4.70 \\
\hline Perforation & 5289.48 & 1.15 & 4121.46 & 0.90 & 4488.21 & 0.98 \\
\hline Edge & $29,172.42$ & 6.35 & $40,407.93$ & 8.79 & $44,728.92$ & 9.73 \\
\hline Loop & 1357.92 & 0.30 & 4939.47 & 1.07 & $10,039.05$ & 2.18 \\
\hline Bridge & 2458.71 & 0.53 & 8933.85 & 1.94 & $19,186.56$ & 4.17 \\
\hline Branch & 6377.22 & 1.39 & $10,598.31$ & 2.31 & $15,255.09$ & 3.32 \\
\hline
\end{tabular}




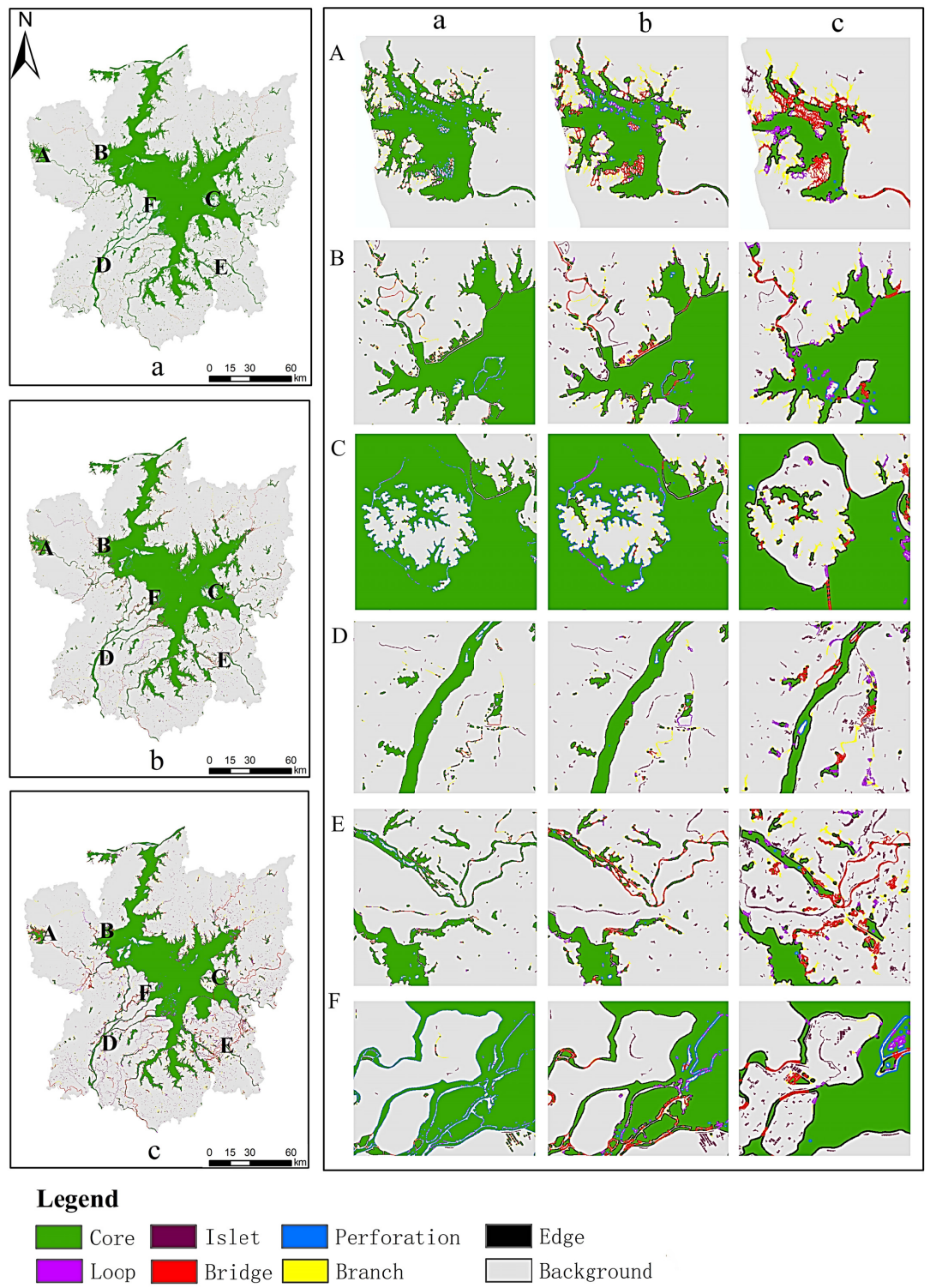

Figure 9. Spatial distribution of each wetland landscape type at different grain sizes in 2020. Note: The letters (a-c) refer to edge widths of (1), (2), and (4), respectively, and the letters (A-F) indicate six sites where the variation in each wetland landscape type is more pronounced.

By comparison, we found that both grain size and edge width influenced MSPA types, albeit in different ways. Zhang et al. [76] found by comparison that the granularity size mainly influenced the combination configuration and quantitative relationship of various landscape types, i.e., as it increased, it may have decreased or increased the spatial information for wetland landscape types. In a study of the Natura 2000 habitat in Spain, Hernando et al. [38] found that edge width had more influence on the results of MSPA classification compared with the granularity size. In particular, the core area was reduced, increasing the edge width. In our study, considering the scale problem and data accuracy in the Poyang Lake area, we selected a resolution of $30 \mathrm{~m}$ and an edge effect width of $60 \mathrm{~m}$; this not only ensured complete landscape information, but also avoided the redundancy of data, which was consistent with the results of Zhang et al. [77] in the Baiyangdian area.

\subsection{Exploring the Drivers of Wetland Hydrological Connectivity}

The Poyang Lake area is a typical wetland landscape in southern China; however, due to the rapid industrialization and urbanization of the region, along with economic changes 
and population growth, the wetland landscape has been significantly altered, as has its hydrological connectivity.

This study found that hydrological connectivity reached its lowest value in 2005. As for natural factors, the decrease in precipitation caused the shrinkage of the wetland area, which led to the decrease in regional hydrological connectivity. Ouyang et al. [78] found that the water level in the Poyang Lake area changed abruptly in 2003, increasing the rate of water level decrease, until it reached its lowest point in 2004. At that time, the wetland area had significantly declined, the core wetland area had decreased, and the hydrological connectivity had its lowest value. As for human factors, Poyang Lake- the largest freshwater lake in China-is located in the middle and lower reaches of the Three Gorges and, as a typical through-river lake, its environment is inevitably affected by the water storage of Three Gorges Project. Since the impoundment of the Three Gorges Dam in 2003, the water inundation area of Poyang Lake has decreased significantly. Zhang et al. [79] found a significant water level decrease after the impoundment of the Three Gorges Project, based on hydrological modeling. The decrease in water level inevitably decreased the wetland area, which decreased hydrological connectivity. Meanwhile, the economic development continuously adjusted the land use structure so that the original wetland area was divided into industrial and agricultural land [80,81]. As industry and agriculture developed, wetland encroachment occurred, and water consumption also increased [82], which directly impacted wetland hydrological connectivity. After 2005, the hydrological connectivity was significantly improved, as the state introduced a series of wetland protection measures for the middle and lower reaches of the Yangtze River [83]. Measures such as returning fields to lakes, and balance of occupation and replenishment, have increased the wetland area, reduced landscape fragmentation, and restored the hydrological connectivity.

In the area around Poyang Lake, wetlands should be returned to farmland, and in each wetland reserve, the development of wetlands should be prohibited in order to provide a good environment for rare birds. To reduce the problem of wetland degradation from the perspective of water circulation, and to improve the local climate with better flood water resource use, the reservoir capacity upstream of the river should be readjusted to increase the amount of water flowing into the downstream wetland. At the same time, dikes or gates should not be built along the river in the floodplain, so as to maintain the natural hydraulic connection between the wetlands and the river.

\section{Conclusions}

In this study, we focused on the spatial and temporal evolution of hydrological connectivity in the Poyang Lake area over the past 31 years, and introduced a method of morphological spatial pattern analysis. The spatial distribution of hydrological connectivity in 7 periods over 31 years was analyzed. Overall, the wetland landscape in the Poyang Lake area has changed drastically, and the wetland area shows a trend of first decreasing and then increasing. By classifying wetlands into different landscape types, we found that the transitions within the wetland landscape and between wetland and non-wetland landscapes were substantial, among which the core wetlands played a dominant role in the hydrological connectivity, which decreased as the core wetland area declined. Transitions within the wetland landscape and between wetland and non-wetland landscapes were also substantial, mainly for core areas, fringe areas, and non-wetland transitions to one another. At the same time, we constructed a comprehensive system of quantitative assessment of hydrological connectivity based on the hydrological connectivity mechanisms and patterns across multiple spatial and temporal scales, and analyzed the hydrological connectivity index from patch to region to landscape scales; this reflected both landscape and functional connectivity, and the index system was not specific to a particular region or a single scale of hydrological connectivity, but was universal. By calculating the hydrological connectivity index, we found that it first decreased and then increased over the study period in the Poyang Lake area. Taking 2005 as the node, we defined the years before 2005 as the "receding" stage of the hydrological connectivity, and after 2005 as the "recovering" stage. 
Prior to 2005, due to natural factors such as decrease in precipitation, as well as man-made factors such as the operation of the Three Gorges Dam, the inlet water volume of Poyang Lake decreased, the wetland landscape was fragmented, and hydrological connectivity decreased. After 2005, wetlands were protected by policies such as "return of fields to lake" and "balance of occupation and replenishment", and increased precipitation expanded the water area and increased hydrological connectivity.

This study investigates the spatial and temporal evolution of eco-hydrological connectivity of wetlands in the Poyang Lake area based on long time series of remote sensing images, but the study lacks exploration of the internal evolution mechanisms of hydrological connectivity. The next step should combine big data and historical information to analyze the evolution of hydrological connectivity of wetlands in detail and clarify the flow paths of materials and energy in order to better assess the quality of the ecological environment of wetlands.

Author Contributions: Conceptualization, Y.X. and C.F.; methodology, Y.X., C.F., and H.L. (Hui Lin); software, Y.X. and H.L. (Huizhong Li); validation, C.F.; formal analysis, Y.X. and B.W.; investigation, H.L. (Hui Lin), C.F., and H.L. (Huizhong Li); resources, Y.X., H.L. (Hui Lin), and C.F.; data curation, Y.X. and H.L. (Huizhong Li); writing-original draft preparation, Y.X., C.F., and B.W.; funding acquisition, Y.X. and C.F. All authors have read and agreed to the published version of the manuscript.

Funding: This work was supported by the National Natural Science Foundation of China (No. U1811464), the Major Project of Art Science of the National Social Science Foundation of China (No. 19ZD27), the Cultural Arts and Tourism Research Project (No. xxhfzzx201907), and the Key Projects of the Key R\&D plan in Jiangxi Province (No. 20192ACB70014).

Institutional Review Board Statement: Not applicable.

Informed Consent Statement: Not applicable.

Data Availability Statement: The data presented in this study are available on request from the corresponding author.

Conflicts of Interest: The authors declare that they have no conflict of interest.

\section{References}

1. Qu, Y.; Luo, C.; Zhang, H.; Ni, H.; Xu, N. Modeling the wetland restorability based on natural and anthropogenic impacts in Sanjiang Plain, China. Ecol. Indic. 2018, 91, 429-438. [CrossRef]

2. Liu, X.; Dong, G.; Wang, X.; Xue, Z.; Jiang, M.; Lu, X.; Zhang, Y. Characterizing the spatial pattern of marshlands in the Sanjiang Plain, Northeast China. Ecol. Eng. 2013, 53, 335-342. [CrossRef]

3. Bracken, L.J.; Croke, J. The concept of hydrological connectivity and its contribution to understanding runoff-dominated geo-morphic systems. Hydrol. Process. 2007, 21, 1749-1763. [CrossRef]

4. Pringle, C. What Is Hydrologic Connectivity and Why Is It Ecologically Important? Hydrol. Process. 2003, 17, 2685-2689. [CrossRef]

5. Ward, J.V. The Four-Dimensional Nature of Lotic Ecosystems. J. N. Am. Benthol. Soc. 1989, 8, 2-8. [CrossRef]

6. Tan, Z.; Li, Y.; Zhang, Q.; Liu, X.; Song, Y.; Xue, C.; Lu, J. Assessing effective hydrological connectivity for floodplains with a framework integrating habitat suitability and sediment suspension behavior. Water Res. 2021, 201, 117253. [CrossRef] [PubMed]

7. Cohen, M.J.; Creed, I.F.; Alexander, L.; Basu, N.B.; Walls, S.C. Do geographically isolated wetlands influence landscape functions? Proc. Natl. Acad. Sci. USA 2016, 113, 1978-1986. [CrossRef] [PubMed]

8. Reckendorfer, W.; Funk, A.; Gschpf, C.; Hein, T.; Schiemer, F. Aquatic ecosystem functions of an isolated floodplain and their implications for flood retention and management. J. Appl. Ecol. 2013, 50, 119-128. [CrossRef]

9. Singh, M.; Sinha, R. Evaluating dynamic hydrological connectivity of a floodplain wetland in North Bihar, India using geostatistical methods. Sci. Total Environ. 2019, 651, 2473-2488. [CrossRef]

10. Gardner, R.C.; Barchiesi, S.; Beltrame, C.; Finlayson, C.; Galewski, T.; Harrison, I.; Paganini, M.; Perennou, C.; Pritchard, D.; Rosenqvist, A. State of the World's Wetlands and Their Services to People: A Compilation of Recent Analyses. Soc. Sci. Electron. Publ. 2015, 158, 348-361. [CrossRef]

11. Wang, J.; Sheng, Y.; Tong, T. Monitoring decadal lake dynamics across the Yangtze Basin downstream of Three Gorges Dam. Remote Sens. Environ. 2014, 152, 251-269. [CrossRef]

12. Zhao, L.; Liu, Y.; Luo, Y. Assessing Hydrological Connectivity Mitigated by Reservoirs, Vegetation Cover, and Climate in Yan River Watershed on the Loess Plateau, China: The Network Approach. Water 2020, 12, 1742. [CrossRef] 
13. Xu, X.; Xie, Y.; Qi, K.; Luo, Z.; Wang, X. Detecting the response of bird communities and biodiversity to habitat loss and fragmentation due to urbanization. Sci. Total Environ. 2018, 624, 1561-1576. [CrossRef]

14. Zhao, R.F.; Zhou, H.R.; Xiao, D.N.; Qian, Y.B.; Zhou, K.F. Changes of wetland landscape pattern in the middle and lower reaches of the Tarim River. Acta Ecol. Sin. 2006, 26, 3470-3478. (In Chinese)

15. Sun, T.; Lin, W.; Chen, G.; Guo, P.; Ying, Z. Wetland ecosystem health assessment through integrating remote sensing and inventory data with an assessment model for the Hangzhou Bay, China. Sci. Total Environ. 2016, 566, 627-640. [CrossRef]

16. Bracken, L.J.; Wainwright, J.; Ali, G.A.; Tetzlaff, D.; Smith, M.W.; Reaney, S.M.; Roy, A.G. Concepts of hydrological connectivity: Research approaches, pathways and future agendas. Earth Sci. Rev. 2013, 119, 17-34. [CrossRef]

17. Li, Y.; Zhang, Q.; Cai, Y.; Tan, Z.; Wu, H.; Liu, X.; Yao, J. Hydrodynamic investigation of surface hydrological connectivity and its effects on the water quality of seasonal lakes: Insights from a complex floodplain setting (Poyang Lake, China). Sci. Total Environ. 2019, 660, 245-259. [CrossRef] [PubMed]

18. Liu, X.; Zhang, Q.; Li, Y.; Tan, Z.; Werner, A.D. Satellite image-based investigation of the seasonal variations in the hydrological connectivity of a large floodplain (Poyang Lake, China). J. Hydrol. 2020, 585, 124810. [CrossRef]

19. Hein, T.; Hauer, C.; Schmid, M.; Stöglehner, G.; Stumpp, C.; Ertl, T.; Graf, W.; Habersack, H.; Haidvogl, G.; Hood-Novotny, R.; et al. The coupled socio-ecohydrological evolution of river systems: Towards an integrative perspective of river systems in the 21st century. Sci. Total Environ. 2021, 801, 149619. [CrossRef]

20. Michalek, A.; Zarnaghsh, A.; Husic, A. Modeling linkages between erosion and connectivity in an urbanizing landscape. Sci. Total Environ. 2021, 764, 144255. [CrossRef]

21. Zhang, Z.; Furman, A. Soil redox dynamics under dynamic hydrologic regimes-A review. Sci. Total Environ. 2021, 763, 143026. [CrossRef]

22. Wang, N.; Chu, X.; Zhang, X. Functionalities of surface depressions in runoff routing and hydrologic connectivity modeling. J. Hydrol. 2021, 593, 125870. [CrossRef]

23. Lehmann, P.; Hinz, C.; Mcgrath, G.; Tromp-Van Meerveld, H.J.; Mcdonnell, J.J. Rainfall threshold for hillslope outflow: An emergent property of flow pathway connectivity. Hydrol. Earth Syst. Sci. 2007, 11, 1047-1063. [CrossRef]

24. McDonough, O.T.; Lang, M.; Hosen, J.; Palmer, M.A. Surface Hydrologic Connectivity Between Delmarva Bay Wetlands and Nearby Streams Along a Gradient of Agricultural Alteration. Wetlands 2015, 35, 41-53. [CrossRef]

25. Uden, D.R.; Hellman, M.L.; Angeler, D.G.; Allen, C.R. The role of reserves and anthropogenic habitats for functional connectivity and resilience of ephemeral wetlands. Ecol. Appl. 2014, 24, 1569-1582. [CrossRef] [PubMed]

26. Vanderhoof, M.K.; Distler, H.E.; Lang, M.W.; Alexander, L.C. The influence of data characteristics on detecting wetland/stream surface-water connections in the Delmarva Peninsula, Maryland and Delaware. Wetl. Ecol. Manag. 2017, 26, 63-86. [CrossRef]

27. Vanderhoof, M.K.; Alexander, L.C.; Todd, M.J. Temporal and spatial patterns of wetland extent influence variability of surface water connectivity in the Prairie Pothole Region, United States. Landsc. Ecol. 2016, 31, 805-824. [CrossRef]

28. Brooks, J.R.; Mushet, D.M.; Van De Rhoof, M.K.; Leibowitz, S.G.; Christensen, J.R.; Neff, B.P.; Rosenberry, D.O.; Rugh, W.D.; Alexander, L.C. Estimating Wetland Connectivity to Streams in the Prairie Pothole Region: An Isotopic and Remote Sensing Approach. Water Resour. Res. 2018, 54, 955-977. [CrossRef]

29. Saura, S.; Estreguil, C.; Mouton, C.; Rodríguez-Freire, M. Network analysis to assess landscape connectivity trends: Application to European forests (1990-2000). Ecol. Indic. 2011, 11, 407-416. [CrossRef]

30. Pascual-Hortal, L.; Saura, S. Comparison and development of new graph-based landscape connectivity indices: Towards the priorization of habitat patches and corridors for conservation. Landsc. Ecol. 2006, 21, 959-967. [CrossRef]

31. Mclaughlin, D.L.; Kaplan, D.A.; Cohen, M.J. A significant nexus: Geographically isolated wetlands influence landscape hydrology. Water Resour. Res. 2014, 50, 7153-7166. [CrossRef]

32. Cavalli, M.; Trevisani, S.; Comiti, F.; Marchi, L. Geomorphometric assessment of spatial sediment connectivity in small Alpine catchments. Geomorphology 2013, 188, 31-41. [CrossRef]

33. Wickham, J.D.; Riitters, K.H.; Wade, T.G.; Vogt, P. A national assessment of green infrastructure and change for the conterminous United States using morphological image processing. Landsc. Urban Plan. 2010, 94, 186-195. [CrossRef]

34. Jia, Y.; Tang, L.; Xu, M.; Yang, X. Landscape pattern indices for evaluating urban spatial morphology-A case study of Chinese cities. Ecol. Indic. 2019, 99, 27-37. [CrossRef]

35. Wang, J.; Xu, C.; Pauleit, S.; Kindler, A.; Banzhaf, E. Spatial patterns of urban green infrastructure for equity: A novel exploration. J. Clean. Prod. 2019, 238, 117858. [CrossRef]

36. Vogt, P.; Riitters, K. GuidosToolbox: Universal digital image object analysis. Eur. J. Remote Sens. 2017, 50, 352-361. [CrossRef]

37. Xiao, Z.; Zhang, W.; Hao, L. The evolution of spatial and temporal patterns of Zhengzhou ecological network based on MSPA. Arab. J. Geosci. 2021, 14, 1107. [CrossRef]

38. Hernando, A.; Velazquez, J.; Valbuena, R.; Legrand, M.; Garcia-Abril, A. Influence of the resolution of forest cover maps in evaluating fragmentation and connectivity to assess habitat conservation status. Ecol. Indic. 2017, 79, 295-302. [CrossRef]

39. Cheng, L.; Xia, N.; Jiang, P.; Zhong, L.; Pian, Y.; Duan, Y.; Huang, Q.; Li, M. Analysis of farmland fragmentation in China Modernization Demonstration Zone since "Reform and Openness": A case study of South Jiangsu Province. Sci. Rep. 2015, 5, 11797. [CrossRef]

40. Vogt, P.; Riitters, K.H.; Iwanowski, M.; Estreguil, C.; Kozak, J.; Soille, P. Mapping landscape corridors. Ecol. Indic. 2007, 7, 481-488. [CrossRef] 
41. Rincón, V.; Velázquez, J.; Gutiérrez, J.; Hernando, A.; Khoroshev, A.; Gómez, I.; Herráez, F.; Sánchez, B.; Pablo Luque, J.; García-abril, A.; et al. Proposal of new Natura 2000 network boundaries in Spain based on the value of importance for biodiversity and connectivity analysis for its improvement. Ecol. Indic. 2021, 129, 108024. [CrossRef]

42. Ghaderpour, E.; Vujadinovic, T.; Hassan, Q.K. Application of the Least-Squares Wavelet software in hydrology: Athabasca River Basin. J. Hydrol. Reg. Stud. 2021, 36, 100847. [CrossRef]

43. Akoko, G.; Le, T.H.; Gomi, T.; Kato, T. A Review of SWAT Model Application in Africa. Water 2021, 13, 1313. [CrossRef]

44. Li, Z.; Sun, W.; Chen, H.; Xue, B.; Yu, J.; Tian, Z. Interannual and Seasonal Variations of Hydrological Connectivity in a Large Shallow Wetland of North China Estimated from Landsat 8 Images. Remote Sens. 2021, 13, 1214. [CrossRef]

45. Wu, Y.; Zhang, Y.; Dai, L.; Xie, L.; Zhao, S.; Liu, Y.; Zhang, Z. Hydrological connectivity improves soil nutrients and root architecture at the soil profile scale in a wetland ecosystem. Sci. Total Environ. 2021, 762, 143162. [CrossRef] [PubMed]

46. Long, C.M.; Pavelsky, T.M. Remote sensing of suspended sediment concentration and hydrologic connectivity in a complex wetland environment. Remote Sens. Environ. 2013, 129, 197-209. [CrossRef]

47. Park, E.; Latrubesse, E.M. The hydro-geomorphologic complexity of the lower Amazon River floodplain and hydrological connectivity assessed by remote sensing and field control. Remote Sens. Environ. 2017, 198, 321-332. [CrossRef]

48. Bian, Z.; Gu, Y.; Zhao, J.; Pan, Y.; Li, Y.; Zeng, C.; Wang, L. Simulation of evapotranspiration based on leaf area index, precipitation and pan evaporation: A case study of Poyang Lake watershed, China. Ecohydrol. Hydrobiol. 2019, 19, 83-92. [CrossRef]

49. Sun, F.; Ma, R.; Liu, C.; He, B. Comparison of the Hydrological Dynamics of Poyang Lake in the Wet and Dry Seasons. Remote Sens. 2021, 13, 985. [CrossRef]

50. Le, X. Assessment of Degradration Causes and Development of Protection Strategies for the Poyang Lake Wetlands. In Chinese Water Systems: Volume 3: Poyang Lake Basin; Yue, T., Nixdorf, E., Zhou, C., Xu, B., Zhao, N., Fan, Z., Huang, X., Chen, C., Kolditz, O., Eds.; Springer International Publishing: Cham, Switzerland, 2019; pp. 113-124. [CrossRef]

51. Xu, J.; Fang, C.; Gao, D.; Zhang, H.; Gao, C.; Xu, Z.; Wang, Y. Optical models for remote sensing of chromophoric dissolved organic matter (CDOM) absorption in Poyang Lake. ISPRS J. Photogramm. Remote Sens. 2018, 142, 124-136. [CrossRef]

52. Feng, W.; Mariotte, P.; Xu, L.; Buttler, A.; Santonja, M. Seasonal variability of groundwater level effects on the growth of Carex cinerascens in lake wetlands. Ecol. Evol. 2020, 10, 517-526. [CrossRef]

53. Wang, Y.; Molinos, J.G.; Shi, L.; Zhang, M.; Xu, J. Drivers and Changes of the Poyang Lake Wetland Ecosystem. Wetlands 2019, 39, 35-44. [CrossRef]

54. Earth Explorer. Available online: https:/ / earthexplorer.usgs.gov / (accessed on 19 November 2021).

55. Geospatial Data Cloud. Available online: https://www.gscloud.cn/search (accessed on 19 November 2021).

56. National Meteorological Information Center-China Meteorological Data Network. Available online: http://data.cma.cn/ (accessed on 19 November 2021).

57. Soille, P.; Vogt, P. Morphological segmentation of binary patterns. Pattern Recogn. Lett. 2009, 30, 456-459. [CrossRef]

58. Sandbech, H. International Evaluation; National Environmental Research Institute: Roskilde, Denmark, 2003.

59. Oliver, M.A.; Webster, R. Kriging: A method of interpolation for geographical information systems. Int. J. Geogr. Inf. Syst. 1990, 4, 313-332. [CrossRef]

60. Miaomiao, L.I.; Bingfang, W.U.; Changzhen, Y. Estimation of Vegetation Fraction in the Upper Basin of Miyun Reservoir by Remote Sensing. Resour. Sci. 2004, 26, 153-159. (In Chinese)

61. Zhang, A.; Xia, C.; Lin, J.; Chu, J. Landscape evolution characteristic index and application. Prog. Geogr. 2018, 37, 811-822. (In Chinese)

62. McGarigal, K.; Compton, B.W.; Plunkett, E.B.; DeLuca, W.; Grand, J.; Ene, E.; Jackson, S.D. A landscape index of ecological integrity to inform landscape conservation. Landsc. Ecol. 2018, 33, 1029-1048. [CrossRef]

63. Feng, H.; Zou, B.; Tang, Y. Scale- and Region-Dependence in Landscape-PM2.5 Correlation: Implications for Urban Planning. Remote Sens. 2017, 9, 918. [CrossRef]

64. Cui, L.; Li, G.; Chen, Y.; Li, L. Response of Landscape Evolution to Human Disturbances in the Coastal Wetlands in Northern Jiangsu Province, China. Remote Sens. 2021, 13, 2030. [CrossRef]

65. Sharp, R.; Chaplin-Kramer, R.; Wood, S.; Guerry, A.; Tallis, H.; Ricketts, T.; Nelson, E.; Ennaanay, D.; Wolny, S.; Olwero, N.; et al. InVEST User's Guide; The Natural Capital Project: Stanford, CA, USA, 2018.

66. Wang, Y.M.; Chin, K.S. Fuzzy analytic hierarchy process: A logarithmic fuzzy preference programming methodology. Int. J. Approx. Reason. 2011, 52, 541-553. [CrossRef]

67. Na, W.; Zhao, Z.C. The comprehensive evaluation method of low-carbon campus based on analytic hierarchy process and weights of entropy. Environ. Dev. Sustain. 2021, 23, 9308-9319. [CrossRef]

68. Wu, H.Y.; Chen, K.L.; Chen, Z.H.; Chen, Q.H.; Qiu, Y.P.; Wu, J.C.; Zhang, J.F. Evaluation for the ecological quality status of coastal waters in East China Sea using fuzzy integrated assessment method. Mar. Pollut. Bull. 2012, 64, 546-555. [CrossRef]

69. Luo, D.; Wen, X.; Xu, J.; Zhang, H.; Vongphet, S. Delineation of groundwater potential zones using modified weight standardization method and GIS in arid environments: Case study of Ejina Oasis, Inner Mongolia, China. Arab J. Geosci. $2021,14,671$. [CrossRef]

70. Leys, C.; Ley, C.; Klein, O.; Bernard, P.; Licata, L. Detecting outliers: Do not use standard deviation around the mean, use absolute deviation around the median. J. Exp. Soc. Psychol. 2013, 49, 764-766. [CrossRef] 
71. Yuan, K.H.; Bushman, B.J. Combining standardized mean differences using the method of maximum likelihood. Psychometrika 2002, 67, 589-607. [CrossRef]

72. Hantila, F.I.; Preda, G. Polarization Method for Static Fields. IEEE Trans. Magn. 2000, 36, 672-675. [CrossRef]

73. Cao, Y.; Meichen, F.U.; Xie, M.; Gao, Y.; Yao, S. Landscape connectivity dynamics of urban green landscape based on morphological spatial pattern analysis(MSPA) and linear spectral mixture model(LSMM) in Shenzhen. Acta Ecol. Sin. 2015, 35, 526-536. [CrossRef]

74. Ya-Ping, Y.U.; Yin, H.W.; Kong, F.H.; Wang, J.J.; Wen-Bin, X.U. Scale effect of Nanjing urban green infrastructure network pattern and connectivity analysis. Chin. J. Appl. Ecol. 2016, 27, 2119-2127. (In Chinese)

75. Ostapowicz, K.; Vogt, P.; Riitters, K.H.; Kozak, J.; Estreguil, C. Impact of scale on morphological spatial pattern of forest. Landsc. Ecol. 2008, 23, 1107-1117. [CrossRef]

76. Zhang, Y.; Shen, W.; Li, M.; Lv, Y. Assessing spatio-temporal changes in forest cover and fragmentation under urban expansion in Nanjing, eastern China, from long-term Landsat observations (1987-2017). Appl. Geogr. 2020, 117, 102190. [CrossRef]

77. Zhang, M.M.; Wu, X.Q. Hydrological connectivity and spatial morphological evolution of Baiyangdian wetlands in the last 20 years. J. Ecol. 2018, 38, 4205-4213. (In Chinese)

78. Ouyang, Q.; Liu, W. Study on the characteristics of water level change of Poyang Lake in the past 50 years. Yangtze River Basin Resour. Environ. 2014, 23, 1545-1550. (In Chinese)

79. Zhang, Q.; Li, L.; Wang, Y.G.; Werner, A.D.; Xin, P.; Jiang, T.; Barry, D.A. Has the Three-Gorges Dam made the Poyang Lake wetlands wetter and drier? Geophys. Res. Lett. 2012, 39, 39. [CrossRef]

80. Han, X.; Chen, X.; Feng, L. Four decades of winter wetland changes in Poyang Lake based on Landsat observations between 1973 and 2013. Remote Sens. Environ. 2015, 156, 426-437. [CrossRef]

81. Velastegui-Montoya, A.; Lima, A.D.; Adami, M. Multitemporal Analysis of Deforestation in Response to the Construction of the Tucuruí Dam. ISPRS Int. J. Geo. Inf. 2020, 9, 583. [CrossRef]

82. Wu, Z.; Liu, T.; Xia, M.; Zeng, T. Sustainable livelihood security in the Poyang Lake Ecological Economic Zone: Identifying spatial-temporal pattern and constraints. Appl. Geogr. 2021, 135, 102553. [CrossRef]

83. Zhang, Y.; Jia, Q.; Prins, H.H.T.; Cao, L.; de Boer, W.F. Effect of conservation efforts and ecological variables on waterbird population sizes in wetlands of the Yangtze River. Sci. Rep. 2015, 5, 17136. [CrossRef] [PubMed] 